\title{
The American Brachinepticula gen. nov. and Manoneura Davis (Nepticulidae): a new generic concept based on a reinforced cathrema in the phallus
}

\author{
Jonas R. Stonis ${ }^{1^{*}}$, \\ Arūnas Diškus', \\ Andrius Remeikis ${ }^{1,2}$, \\ Maria Alma Solis ${ }^{3}$ \\ ${ }^{1}$ Lithuanian University \\ of Educational Sciences \\ and Baltic-American \\ Biotaxonomy Institute, \\ Studentu St. 39, \\ Vilnius 08106, Lithuania \\ ${ }^{2}$ Institute of Ecology, \\ Nature Research Centre, \\ Akademijos St. 2, \\ Vilnius 08412, Lithuania \\ ${ }^{3}$ Systematic Entomology Laboratory, \\ ARS, USDA, National Museum \\ of Natural History, \\ Smithsonian Institution, \\ Washington, D.C., \\ 20013-7012, USA
}

We describe one new genus (Brachinepticula Stonis \& Diškus, gen. nov.) with two new species (B. plurilobata Diškus \& Stonis, sp. nov., B. elongata Remeikis \& Stonis, sp. nov.), and one species with uncertain taxonomic position (Johanssoniella bina Remeikis \& Stonis, sp. nov.). We also provide diagnostic characters and an updated annotated catalogue of the following related genera: newly restored Johanssoniella Koçak, Brachinepticula gen. nov., Enteucha Meyrick (s. str.) and Manoneura Davis. In the Annotated Catalogue, we provide five new combinations and new data on morphology, biology, and distribution of some species, including the first photographic documentation of Manoneura basidactyla Davis discovered in the Amazon rainforest, results of re-examination of the male genitalia of the European Johanssonia acetosae (Stt.), also the first documentation of the male genitalia, host plant and leaf mines of the little known Johanssoniella diplocosma (Meyrick) from the Himalayas. All new taxa treated in the paper are illustrated with drawings and (or) photographs of the adults and genitalia; photographs of the leaf mines of Brachinepticula plurilobata Diškus \& Stonis, sp. nov. and Johanssoniella diplocosma (Meyrick) are also provided.

Keywords: American fauna, Brachinepticula Stonis \& Diškus, Enteucha Meyrick, Johanssoniella Koçak, leaf mines, Manoneura Davis, Nepticulidae, new genus, new species

\section{INTRODUCTION}

Among leaf-mining pygmy moths (Lepidoptera, Nepticulidae), there are over a dozen described (and many undescribed) nepticulid species which we informally name the "Enteucha-like assemblage". These species are characterized by the lamellar col-

\footnotetext{
* Corresponding author. Email: stonis@leu.lt
}

lar (homologous to the collar of Stigmella Schrank, Simplimorpha Scoble, and a few other genera), absence of transtilla in the male genitalia (paralleled in Glaucolepis Braun and some other taxa), the distinctive band-like tegumen, extremely weak or totally undeveloped cornuti, and reduced forewing venation lacking either vein $\mathrm{CuA}$ or Rs4. Some species of this "assemblage" occur in North America, Europe, and Asia, however, the majority occur in Central and South America, and namely they include some 
of the most striking representatives in the Neotropical fauna with remarkable forewing coloration and with distictively modified structures of the genitalia. Host-plant preferences are still unknown for nearly two-thirds of the species, but species with known biology feed on Polygonaceae plants. Phylogenetically this "assemblage" has been found to be a sister group to Stigmella Schrank (Puplesis, 1994) or to all remaining Nepticulidae (Doorenweerd et al., 2016).

In recent literature, species from the "Enteucha-like assemblage" were either divided between two genera (Enteucha Meyrick and Manoneura Davis; see Davis, 1978, 1979; Puplesis \& Robinson, 2000; Puplesis et al. 2002b; Diškus \& Puplesis, 2003; Stonis et al., 2017) or treated as belonging to one genus (Enteucha Meyrick, sensu lato; see van Nieukerken, 1986a; 1986b, van Nieukerken et al., 2016a).

Recent molecular research (Regier et al., 2013; Doorenweerd et al., 2016) indicated a heterogeneity of this artifical assemblage. Despite a very few shared characters, including the variously reduced wing venation, morphology of these species shows a great diversity (Figs. 1-4). In the course of our recent study of the "Enteuchalike assemblage", we discovered novel morphological characters, notably the presence of vaginal sclerites in the female genitalia, and a greatly developed pseudoanellus, and a strongly reinforced cathrema of the phallus in the male genitalia. The term "cathrema" was proposed by Schoorl et al. (1985) and is characteristic of all Nepticulidae (i.e., an apomorphy of the family). It represents a striate or smooth thickening at the base of the ductus ejaculatorius and is variously developed in different genera of Nepticulidae. Among the species of the "Enteucha-like assemblage", we can observe cathrema rather weakly developed (Fig. 3) in Enteucha or extremely weakly developed, indistinctive or maybe even absent (Fig. 1) in Johanssoniella. However, there are two putative monophyletic clusters of species, each of which exhibit strongly reinforced cathrema: either with unique, very long, lateral processes in Brachinepticula gen. nov. described here (see Fig. 2) or in the genus Manoneura, cathrema strongly extended caudally (Fig. 4). It is interest- ing to note that these latter unusual evolutionary trends are paralleled with another morphological feature of Brachinepticula gen. nov. and Manoneura - the absence of cornuti (Figs. 2, 4) so characteristic of the vast majority of Nepticulidae outside of the "Enteucha-like assemblage".

For researchers studying the American Nepticuloidea, it does not take very long to perceive that Manoneura Davis represents a truly exotic genus, the most distinctive and probably most beautiful and endemic element of the Neotropical Nepticulidae fauna. Externally, the species of Manoneura are very distinctive because of the strong purple or ochreous golden lustre (see Figs. 93-98) and internally the highly modified uncus and gnathos of Manoneura form a unique, movable, lock-like formation (Figs. 80, 83, 89). Moreover, the phallus has distinctive carinae, the sublateral process of the valva is unusually enlarged, the vinculum has a specific lateral thickening (apodeme), and the valva has a dorsal process (Fig. 4). Additionally, the strongly developed cathrema makes the genus even more derived. The recently described Peruvian Manoneura forcipis Remeikis \& Stonis (Stonis et al., 2017) probably represents the most outstanding example: the cathrema is protruding from the phallus (Fig. 81). Similarly, although not so strongly reinforced, a cathrema is observed in other species of Manoneura (Figs. 79, 84) and species of Brachinepticula gen. nov. (Figs. 2, 15, 22). To accommodate the markedly apomorphic Manoneura (Fig. 4) and newly recognized Brachinepticula genus (Fig. 77) within the classification of Nepticulidae and the "Enteucha-like assemblage" in particular, we needed a new taxonomic concept of four genera (or five including the monotypic African Varius Scoble). Detailed characterizations of all these genera are provided in Fig. 1 and additionally discussed after each genus in the Annotated Catalogue below. Now it appears that the earlier synonymization of Johanssoniella Koçak (= Johanssonia Borkowski) with Enteucha by van Nieukerken (1986a) and followed by Puplesis (1994) and Diškus \& Puplesis (2003) was premature. The generic status of Johanssoniella (Fig. 1) is restored, although it can be characterized only by a very 
few apomorphies (we expect more will be found in the future) (also see Discussion in the Annotated Catalogue). We also describe one new genus, Brachinepticula Stonis \& Diškus, with two new species (B. plurilobata Diškus \& Stonis, sp. nov., B. elongata Remeikis \& Stonis, sp. nov.), and one species with an uncertain taxonomic position (Johanssoniella bina Remeikis \& Stonis, sp. nov.). We provide an updated Annotated Catalogue for the related genera of the "Enteucha-like assemblage". We also provide the first photographic documentation of Manonera basidactyla discovered in the Amazon rainforest, the results of re-examination of male genitalia of the European Johanssoniella acetosae (Stt.), and the first documentation of male genitalia, host plant, and leaf mines of the little known Johanssoniella diplocosma (Meyrick) from the Himalayas.

\section{MATERIALS AND METHODS}

Descriptions of new taxa are based on material deposited in the collection of the Zoological Museum, Natural History Museum of Denmark, Copenhagen, Denmark (ZMUC), collected in Argentina (by E. S. Nielsen and Ole Karsholt, Mision Cientifica Danesa) and Ecuador (by Arūnas Diškus and J. R. Stonis). Other material in the current paper was mostly received from the USNM, and also from other institutions including the BMNH, ZIN, and LEU.

Methods and protocols for species identification and description are outlined in Puplesis (1994), Puplesis \& Robinson (2000), Puplesis \& Diškus (2003), and Stonis et al. (2016).

Preparation of temporary and permanent micro-mounts of genital structures was undertaken following the method by Stonis et al. (2014). After maceration of the abdomen in $10 \% \mathrm{KOH}$ and subsequent cleaning, abdominal pelts and female genitalia were stained with Chlorazol Black (Direct Black 38/Azo Black), and male genitalia were left unstained. Male genital capsules were removed from the abdomen and mounted ventral side uppermost. The phallus was severed from the genital capsule. Both male and female genitalia were mounted in Euparal.
Permanent slides were photographed and studied using a Leica DM2500 microscope and Leica DFC420 digital camera.

The descriptive terminology of morphological structures follows Johansson et al. (1990) and Puplesis \& Robinson (2000), except for the term "aedeagus", which is referred here as "phallus" and the term "cilia", which is referred here as "fringe".

Institutional abbreviations used in the text:

BMNH - The Natural History Museum, London, United Kingdom;

LEU - Lithuanian University of Educational Sciences (formerly VPU), Vilnius, Lithuania;

USNM - United States National Museum of Natural History, Smithsonian Institution, Washington, D.C., USA;

ZIN - Zoological Institute of the Russian Academy of Sciences, St. Petersburg, Russia;

ZMUC - Zoological Museum, University of Copenhagen, Denmark.

\section{DESCRIPTION OF BRACHINEPTICULA STONIS \& DIŠKUS, GEN. NOV.}

Type species. Brachinepticula plurilobata Diškus \& Stonis, sp. nov. by present designation.

Diagnosis (Figs. 1-4). Brachinepticula is recognised by the presence of well-developed pseudoanellus and distinctive, paired juxta, long lateral processes of cathrema, also lobate valva in the male genitalia, and the vaginal sclerites in the female genitalia. Wing venation with a separate vein $\mathrm{CuA}$. As far as we know, blotch-like leaf mines also make this genus distinctive.

Description. Adult (Figs. 5-7). Rather small nepticulid moths, forewing length $1.8-2.5 \mathrm{~mm}$; wingspan 5.1-5.5 mm. Head (Figs. 8, 9): palpi greyish cream to grey brown; maxillary palpus four-segmented; labial palpus three-segmented; frontal tuft beige cream to orangish yellow; collar distinctive, comprised of lamellar scales; scape large; male antenna longer than half of the length of forewing; flagellum (Fig. 10) with 36 segments in female, 43-45 in male. Forewing dark, with or without purple iridenscence, uniformly coloured or with two fasciae (Fig. 5); fringe grey-brown, without fringe line; underside of forewing without spots or androconia. 


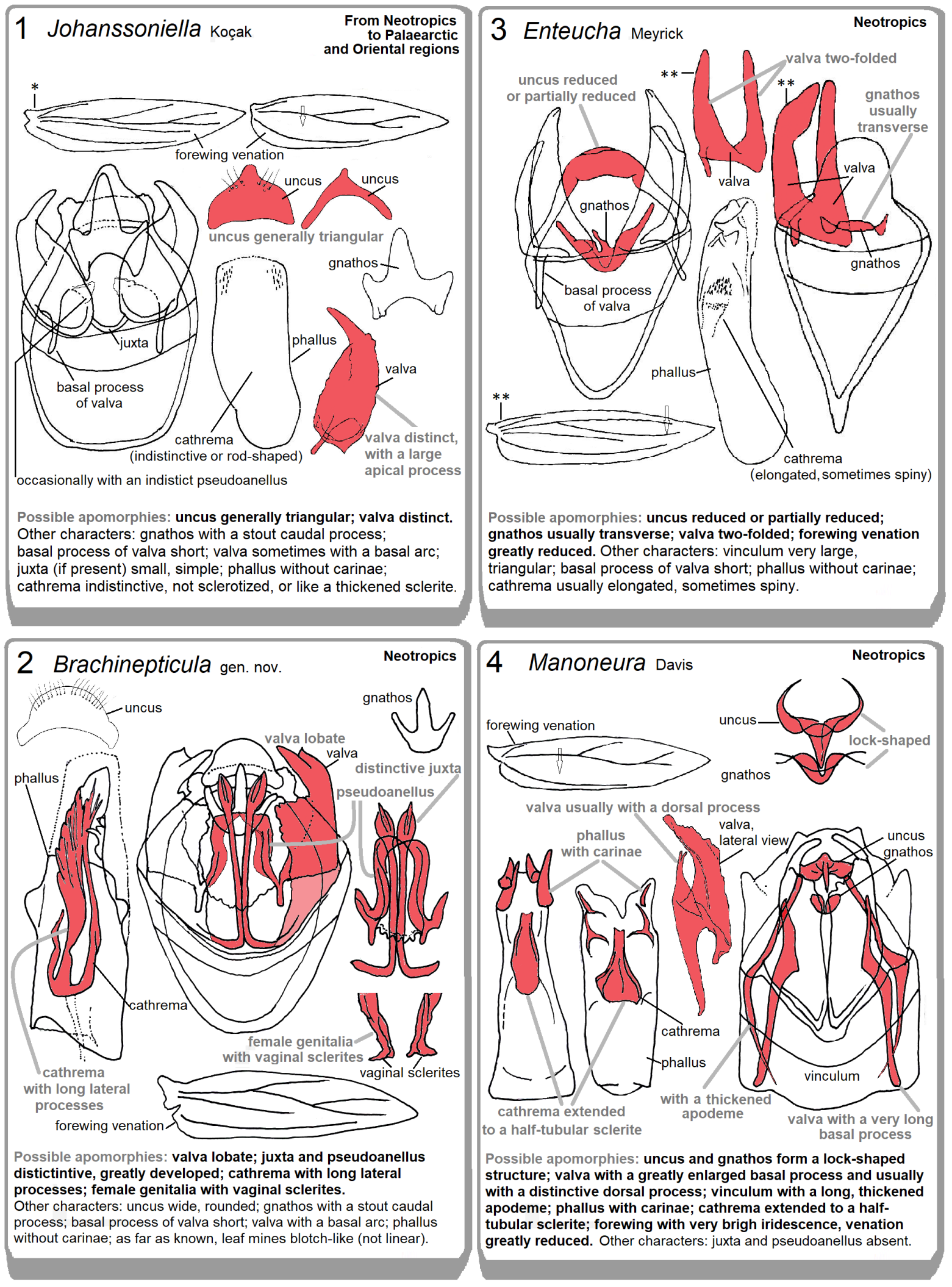

Figs. 1-4. Diagnostics of Johanssoniella Koçak, Brachinepticula gen. nov., Enteucha Meyrick (s. str.), and Manoneura Davis

* - after van Nieukerken, 1986, modified; ${ }^{* *}$ - after Davis, 1978, modified. 


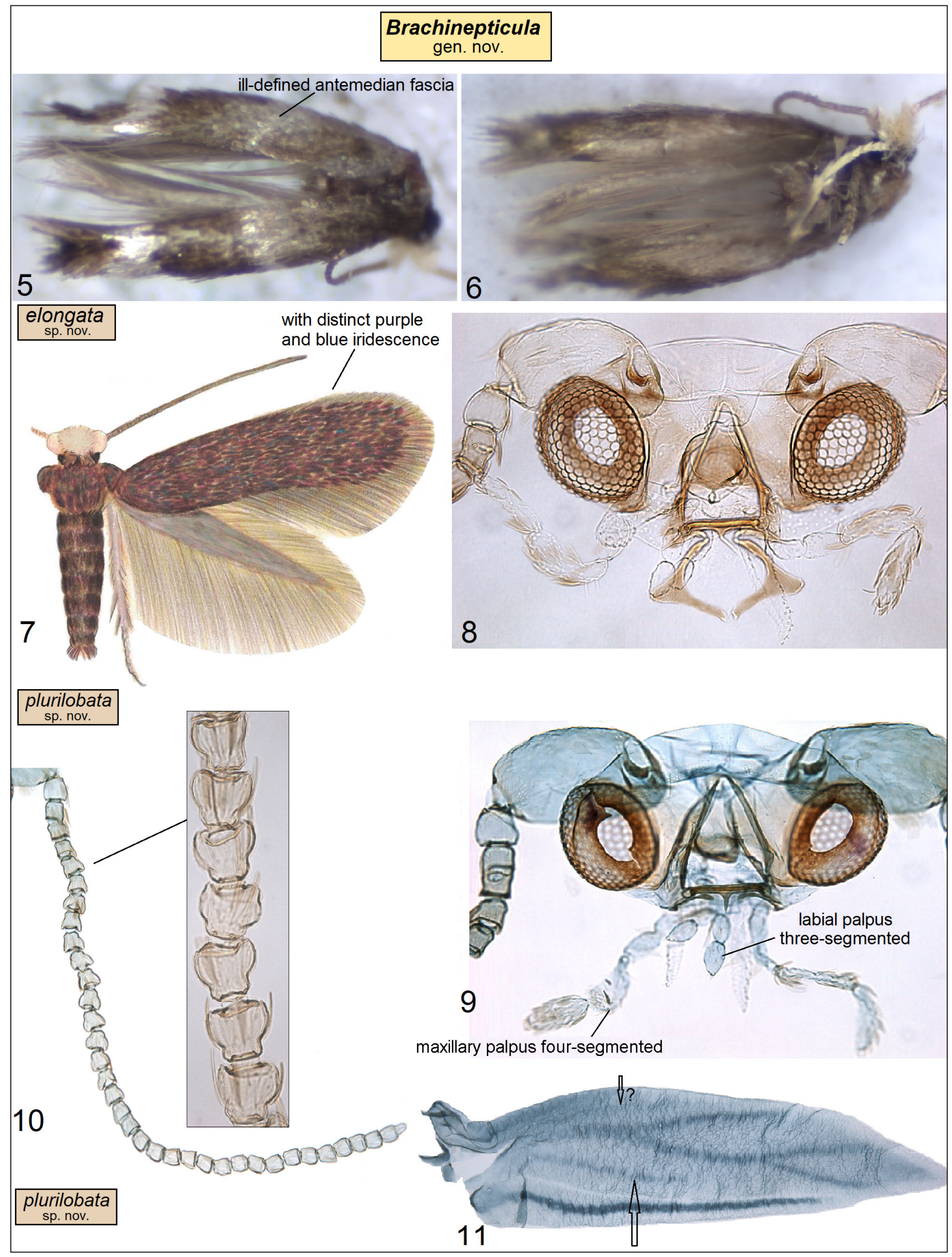

Figs. 5-11. Morphology of Brachinepticula gen. nov. 5 - Brachinepticula elongata Remeikis \& Stonis, sp. nov., male adult, dorsal view; 6 - same, ventral view; 7 - B. plurilobata Diškus \& Stonis, sp. nov., male adult, reconstructed, enhanced; 8 - same, descaled head, slide no. AD686; 9 - same, slide no. AD687; 10 - same, descaled flagellum, slide no. AD686; 11 - same, forewing venation, slide no. AD689 (ZMUC) 
Forewing venation (Fig. 11) with a separate $\mathrm{CuA}$. Hindwing lanceolate, without androconia. Male abdomen with two distinctive anal tufts.

Female. Similar to male but tends to be paler. Flagellum of antenna with about 36 segments.

Male genitalia (Figs. 2, 12-30). Capsule longer $(285-380 \mu \mathrm{m})$ than wide $(140-280 \mu \mathrm{m})$. Tegumen band-like (Fig. 23). Uncus wide, rounded (Fig. 24), without caudal protrusion. Gnathos with one stout caudal process, slender lateral arms, and with or without central plate (Figs. 14, 25). Valva lobate, with a basal arc; transtilla absent; pseudoanellus well developed, arising from basal processes of valva (Fig. 26). Juxta paired, distally pointed and (or) elaborated, arising from basal arc (Fig. 26). Vinculum without lateral lobes, widely rounded or triangular. Phallus angular (Figs. 28-30) or almost rounded basally (Figs. 15, 16), 260-310 $\mu \mathrm{m}$ long, without cornuti on vesica; cathrema with very long, lateral processes (Figs. 2, 15, 28-30).

Female genitalia (Fig. 32). Relatively short, total length about $490 \mu \mathrm{m}$. Anterior apophyses lobe-like, slender only distally, but without distinctive distal processes; posterior apophyses slender, rod-like. Genitalia with two large, heavily chitinized vaginal sclerites (Figs. 31, 33). Corpus bursae partially reduced, weakly sclerotized, without signum or pectinations. Accessory sac heavily folded; ductus spermathecae without distinctive coils. Abdominal tip wide, rounded.

Bionomics (Figs. 36-47). Larvae of the type species, Brachinepticula plurilobata sp. nov., mine in leaves in January. Host plant: we were unable to determine the genus and species of the plant, but it belongs to the Polygonaceae family. Leaf mine starts as a short but very slender gallery; later on it develops to a blotch with frass accumulated in the centre of the blotch (Fig. 45). Larva spins its cocoon outside the mine. Cocoon of the type species oval-shaped, very pale, almost cream. Pupa illustrated in Figs. 41-43.

Distribution (Fig. 48). The species of the new genus occur on the western slopes of the equatorial (northern) Andes and on the eastern slopes of central Andes at altitudes up to $2700 \mathrm{~m}$.

Etymology. The genus name is derived from the Latin brachiata (branched) and Nepticula (synonymous name for the genus Stigmella) in reference to the lobate valva, paired juxta, and divided pseudoanellus in the male genitalia.

Discussion. From Johanssoniella Koçak (Fig. 1), the new genus Brachinepticula gen. nov. differs in the unique cathrema with long lateral processes (cathrema indistinctive or stickshaped in Johanssoniella), presence of a strongly developed pseudoanellus, widely rounded uncus (usually triangular in Johanssoniella), complex, lobate valva (usually simple, triangular in Johanssoniella), and the presence of vaginal sclerites in the female genitalia.

From Enteucha Meyrick (Fig. 3), the new genus differs in the cathrema with long lateral processes, the presence of distinct, widely rounded uncus (reduced or partially reduced in Enteucha), gnathos with a stout caudal process (without a stout caudal process, usually transverse in Enteucha), the presence of pseudoanellus and juxta (absent in Enteucha), less reduced forewing venation (see Figs. 2 and 3), and the presence of vaginal sclerites in the female genitalia.

From Manoneura Davis (Fig. 4), the new genus differs in the presence of pseudoanellus and juxta, widely rounded uncus, gnathos with a stout caudal process (in Manoneura, unique uncus, and gnathos form of a lock-shaped structure), short basal process of valva (very long in Manoneura), absence of a thickened apodeme of vinculum (present in Manoneura), phallus without carinae (with distinct carinae in Manoneu$r a$ ), cathrema with long processes (half-tubular, without lateral process in Manoneura), the presence of vaginal sclerites in the female genitalia, and the less reduced forewing venation, with a separate $\mathrm{CuA}$ (see Figs. 2 and 4).

\section{Brachinepticula elongata Remeikis \& Stonis, sp. nov.}

(Figs. 5, 6, 12-17, 48)

Type material. Holotype: $\widehat{\partial}$, ARGENTINA, Salta, Rosario de la Frontera, Los Banos, 11.iv.1979, Mision Cientifica Danesa (E. S. Nielsen et al.), genitalia slide no. RA625 $ठ$ (ZMUC).

Diagnosis. The combination of the forewing with a fascia, short juxta, valva with pointed apical process and slender inner lobe, triangular 


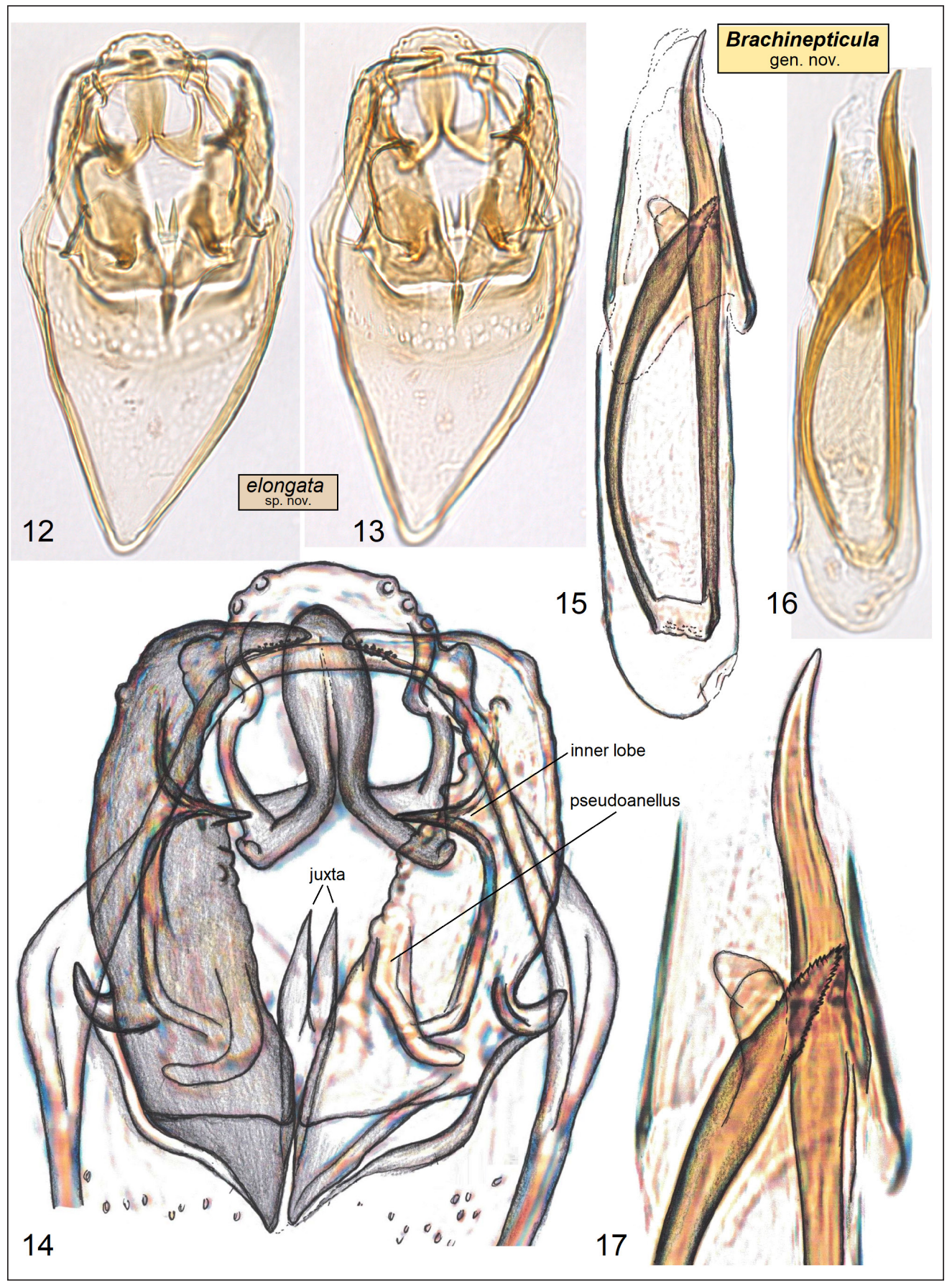

Figs. 12-17. Male genitalia of Brachinepticula elongata Remeikis \& Stonis, sp. nov., holotype, genitalia slide no. RA625 (ZMUC). 12, 13 - capsule with phallus removed, 14 - same, enhanced; $15-17$ - phallus

vinculum, and unique processes of cathrema in the phallus distinguishes B. elongata sp. nov. from all Nepticulidae species, including the related B. plurilobata Diškus \& Stonis, sp. nov.

Male (Figs. 5, 6). Forewing length about $1.8 \mathrm{~mm}$; wingspan about $5.1 \mathrm{~mm}$. Head: palpi grey-brown; frontal tuft very pale, orangish yellow; collar distinctive, comprised of lamellar scales, grey cream; scape cream; flagellum of antenna brown on upper side, pale brown on underside; number of segments unknown. Thorax and tegula dark grey-brown. Forewing 
dark grey-brown, with two silvery shiny fasciae: ill-defined antemedian and wide postmedian; fringe grey-brown; underside of forewing brown, without spots or androconia. Hindwing and its fringe very pale brown on upper side and underside. Legs brown on upper side, pale brown to brownish cream on underside.

\section{Female. Unknown.}

Male genitalia (Figs. 12-17). Capsule significantly longer $(285-290 \mu \mathrm{m})$ than wide $(140-150 \mu \mathrm{m})$. Uncus wide, rounded. Gnathos with one wide caudal process; central plate absent; lateral arms long and slender. Valva 125-130 $\mu \mathrm{m}$ long, $50 \mu \mathrm{m}$ wide, with a large, apical process and very slender, inner lobe; transtilla absent; pseudoanellus present, indistinctive. Juxta short, but distinctly paired, distally pointed. Vinculum very long, triangular, without lateral lobes. Phallus (Figs. 15-17) 310-315 $\mu \mathrm{m}$ long, 50-65 $\mu \mathrm{m}$ wide, without cornuti on vesica; cathrema with two very long lateral processes.

Bionomics. Adults fly in April. Otherwise biology unknown.

Distribution (Fig. 48). This species occurs in Argentina on the eastern slopes of the Andes, in the Jungas biogeographical province, at an elevation of about $750 \mathrm{~m}$.

Etymology. The species name is derived from the Latin elongatus (meaning distant or remote from) in reference to the unique, slender male genitalia with greatly extended processes of the cathrema.

\section{Brachinepticula plurilobata Diškus \& Stonis, sp. nov.}

(Figs. 7-11, 18-48)

Type material. Holotype: $\partial^{\lambda}$ ECUADOR: Pichincha Province, 24 km NW Alóag, $0^{\circ} 27^{\prime} 07^{\prime \prime}$, $78^{\circ} 41^{\prime} 00^{\prime \prime} \mathrm{W}$, elevation $2720 \mathrm{~m}$, mining larvae on Muehlenbeckia sp., 14.i.2005, field card no. 4814, leg. A. Diškus, J. R. Stonis, genitalia slide no.

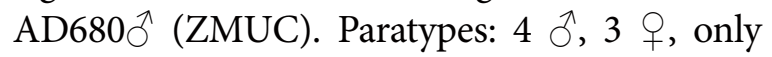
from mature pupae, label data as holotype, slides no. $\mathrm{AD} 681 \hat{\circ}, \mathrm{AD} 682 \hat{\jmath}, \mathrm{AD} 897 \hat{\sigma}, \mathrm{AD} 902 \hat{\jmath}$, AD683어, AD684우, AD686우 (head), AD687우 (head), AD689ㅇ (wing venation), $\mathrm{AD} 901 \%$ (ZMUC).
Diagnosis. The combination of the uniform forewing without fascia, long juxta, strongly developed pseudoanellus, three-lobed valva, widely rounded vinculum, and unique processes of the cathrema in the phallus distinguishes B. plurilobata sp. nov. from all Nepticulidae species, including the related $B$. elongata Remeikis \& Stonis, sp. nov.

Male (Figs. 7-11). Forewing length about $2.5 \mathrm{~mm}$; wingspan about $5.5 \mathrm{~mm}$. Head: maxillary palpus greyish cream; frontal tuft large, beige cream; collar distinctive, comprised of lamellar scales, grey-brown, glossy; scape cream, glossy; antenna significantly longer than half of the length of forewing; flagellum with 43-45 segments, brown with little green iridescence. Thorax, tegula and forewing densely speckled with dark grey-brown scales with distinctive purple and blue iridescence. Forewing without fascia; fringe grey-brown; underside of forewing grey-brown, without spots or androconia. Forewing venation (Fig. 11) with a separate vein $\mathrm{CuA}$. Hindwing pale grey-brown with little purple iridescence on upper side; its fringe pale grey-brown with some golden gloss. Legs brownish cream to brown, with golden gloss; foreleg darkened with fuscous brown scales on upper side. Abdomen dark fuscous brown on upper side and underside; genital plates brownish grey, anal tufts distinctive, brown.

Female. Similar to male but tends to be paler. Flagellum of antenna with about 36 segments.

Male genitalia (Figs. 18-30). Capsule longer $(375-380 \mu \mathrm{m})$ than wide $(270-280 \mu \mathrm{m})$. Uncus wide, rounded. Gnathos with one stout caudal process, central plate, and slender arms. Valva 235-240 $\mu \mathrm{m}$ long, 75-80 $\mu \mathrm{m}$ wide, lobate; transtilla absent; pseudoanellus strongly developed, arising from basal process of valva. Juxta long, paired, distally eleborated. Vinculum without lateral lobes, widely rounded. Phallus with chitinized lateral lobes (Figs. 22, 28-30), angular, 240-260 $\mu \mathrm{m}$ long, $80 \mu \mathrm{m}$ wide basally, without cornuti on vesica; cathrema with very large lateral processes.

Female genitalia (Figs. 31-35). Total length about $490 \mu \mathrm{m}$. Anterior apophyses lobe-like, slender only distally, shorter than posterior 
apophyses. Genitalia with two large vaginal sclerites (Figs. 31, 33, 35). Corpus bursae partially reduced, weakly sclerotized; signum or pectinations absent. Accessory sac rounded, very heavily folded; ductus spermathecae chitinized, sinuous but without distinctive coils. Abdominal tip very wide, rounded.

Bionomics (Figs. 36-47). Larvae mine in leaves in January. Host plant: Muehlenbeckia Meisn., M. tamnifolia (Kunth) Meisn. or most

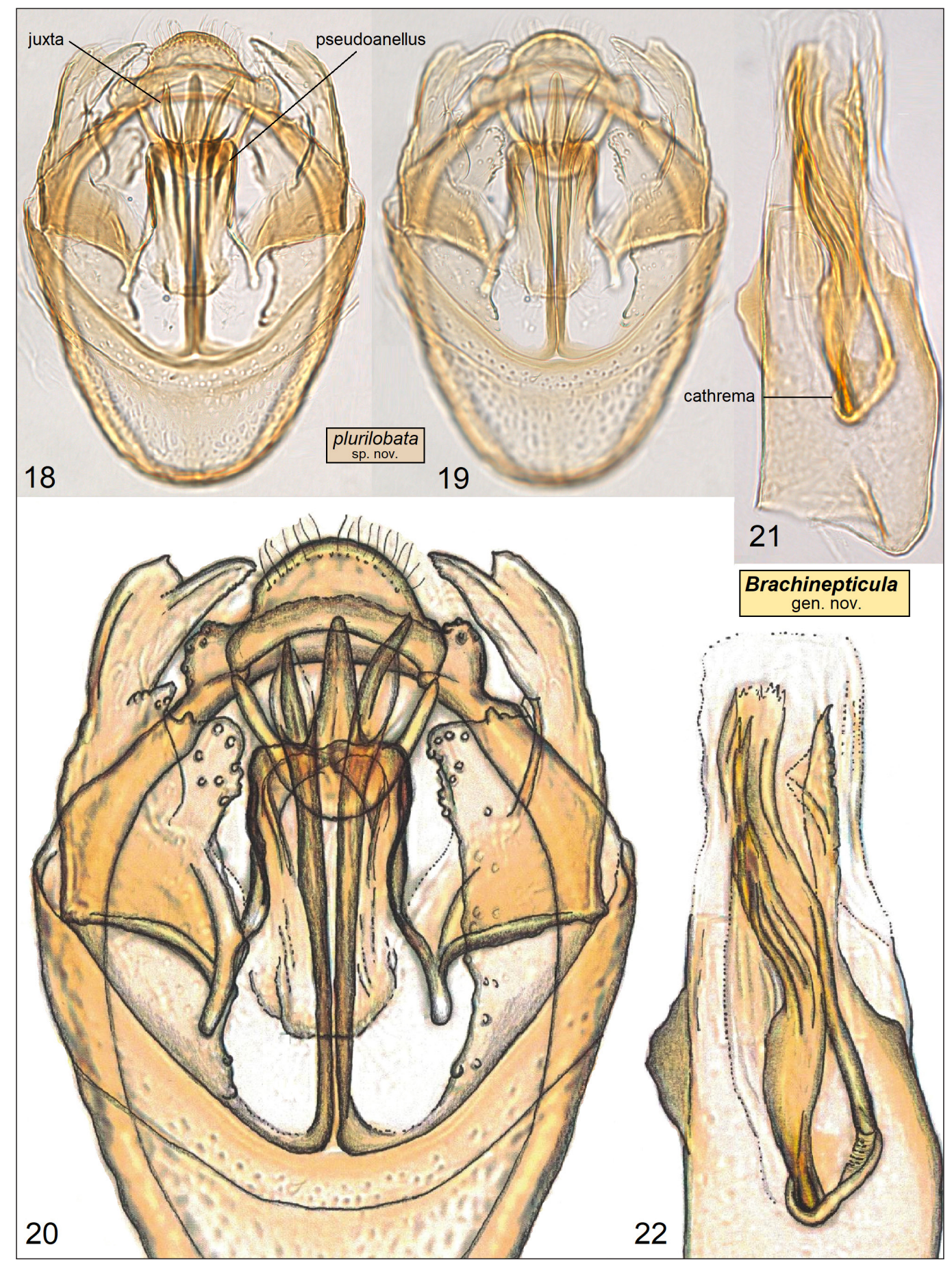

Figs. 18-22. Male genitalia of Brachinepticula plurilobata Diškus \& Stonis, sp. nov., holotype, genitalia slide no. AD680 (ZMUC). 18, 19 - capsule with phallus removed, 20 - same, enhanced; 21 - phallus; 22 - same, enhanced 


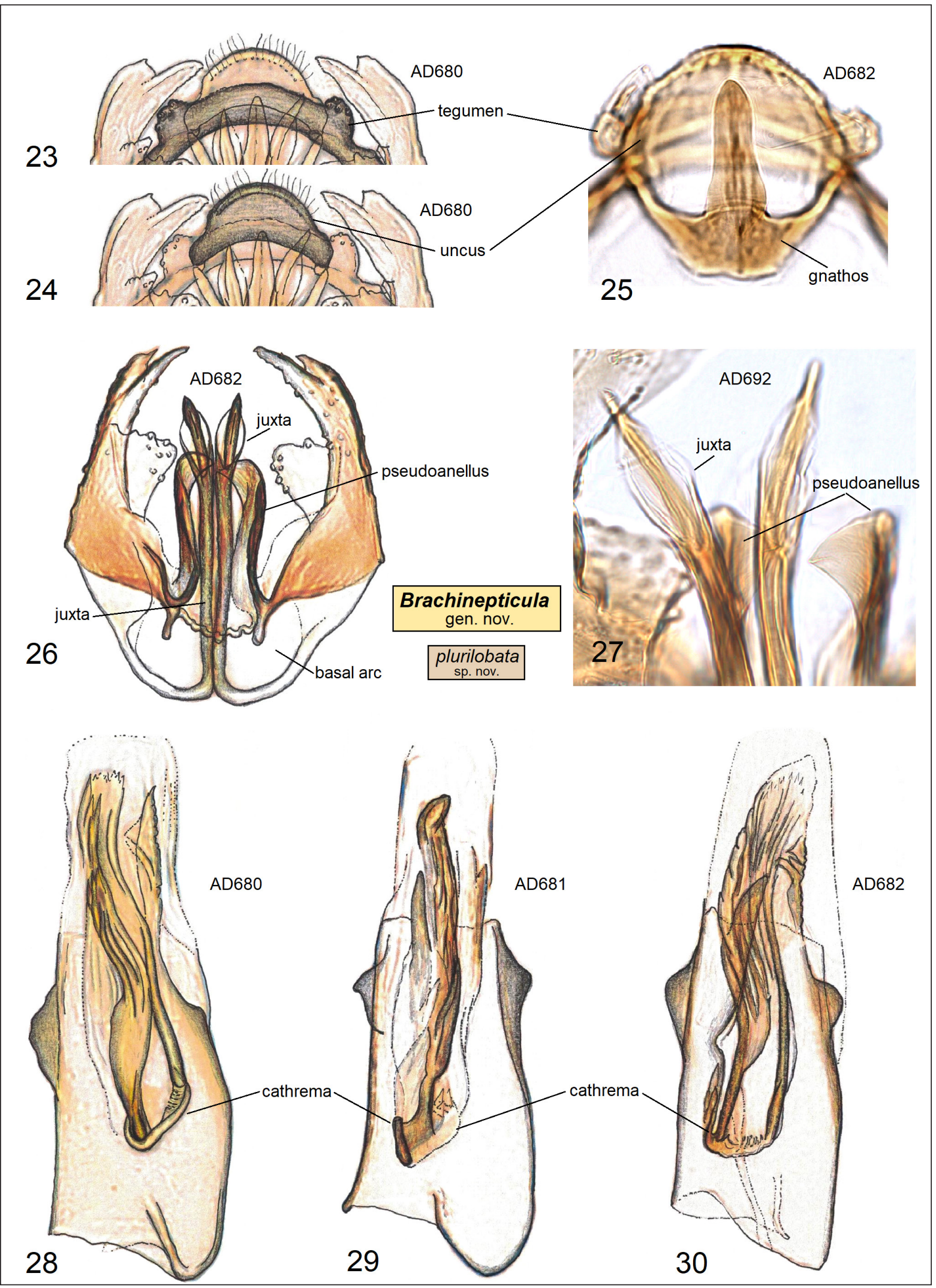

Figs. 23-30. Male genitalia of Brachinepticula plurilobata Diškus \& Stonis, sp. nov. 23 - tegumen; 24 - uncus; 25 - gnathos; 26, 27 - pseudoanellus and juxta; 28-30 - phallus (ZMUC) 


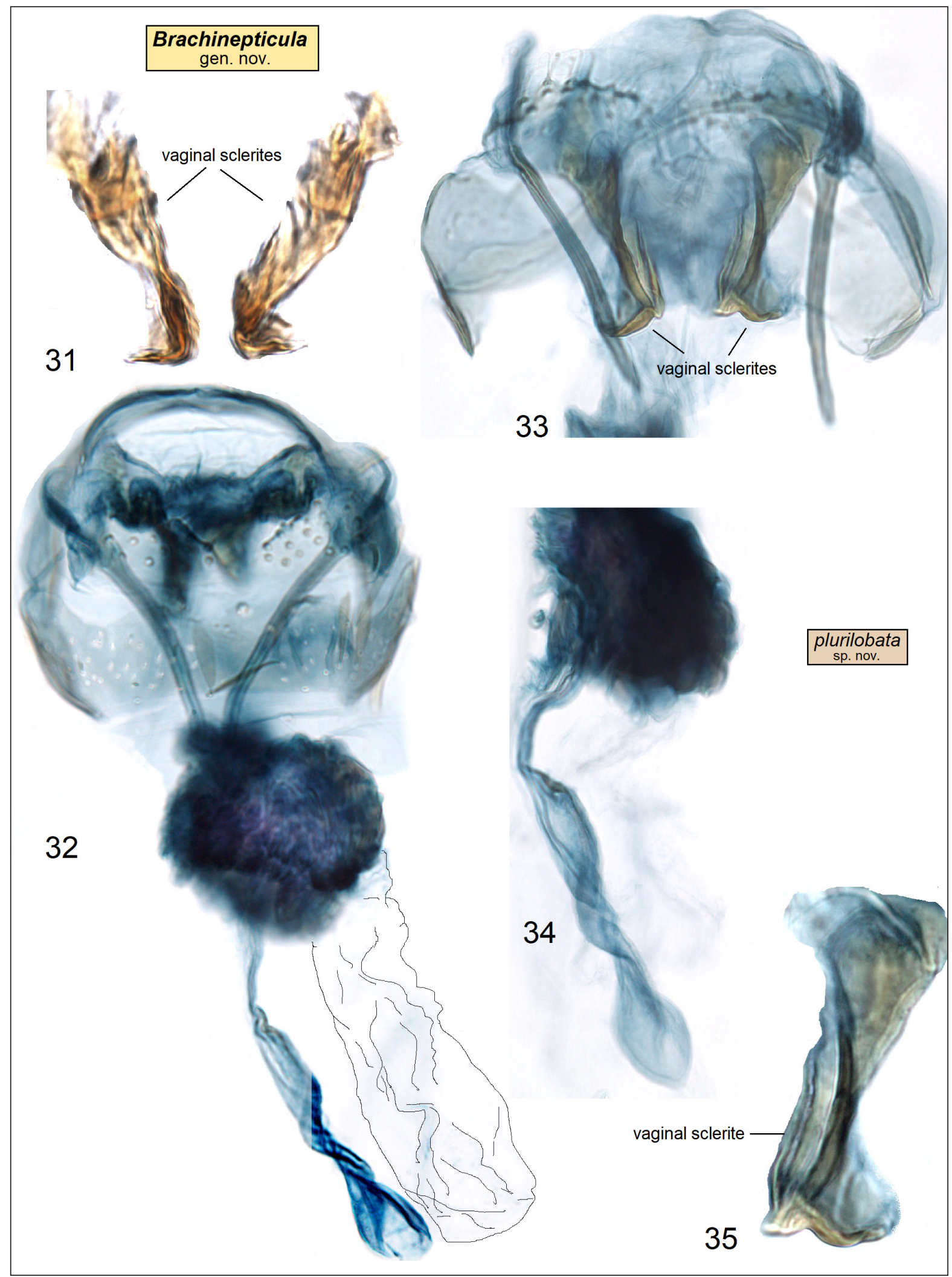

Figs. 31-35. Female genitalia of Brachinepticula plurilobata Diškus \& Stonis, sp. nov. 31 - vaginal sclerites, slide no. AD901; 32 - general view, slide no. AD683; 33 - apophyses and vaginal sclerites, slide AD684; 34 - ductus spermathecae, slide AD683; 35 - vaginal sclerite, slide no. AD684 (ZMUC) 


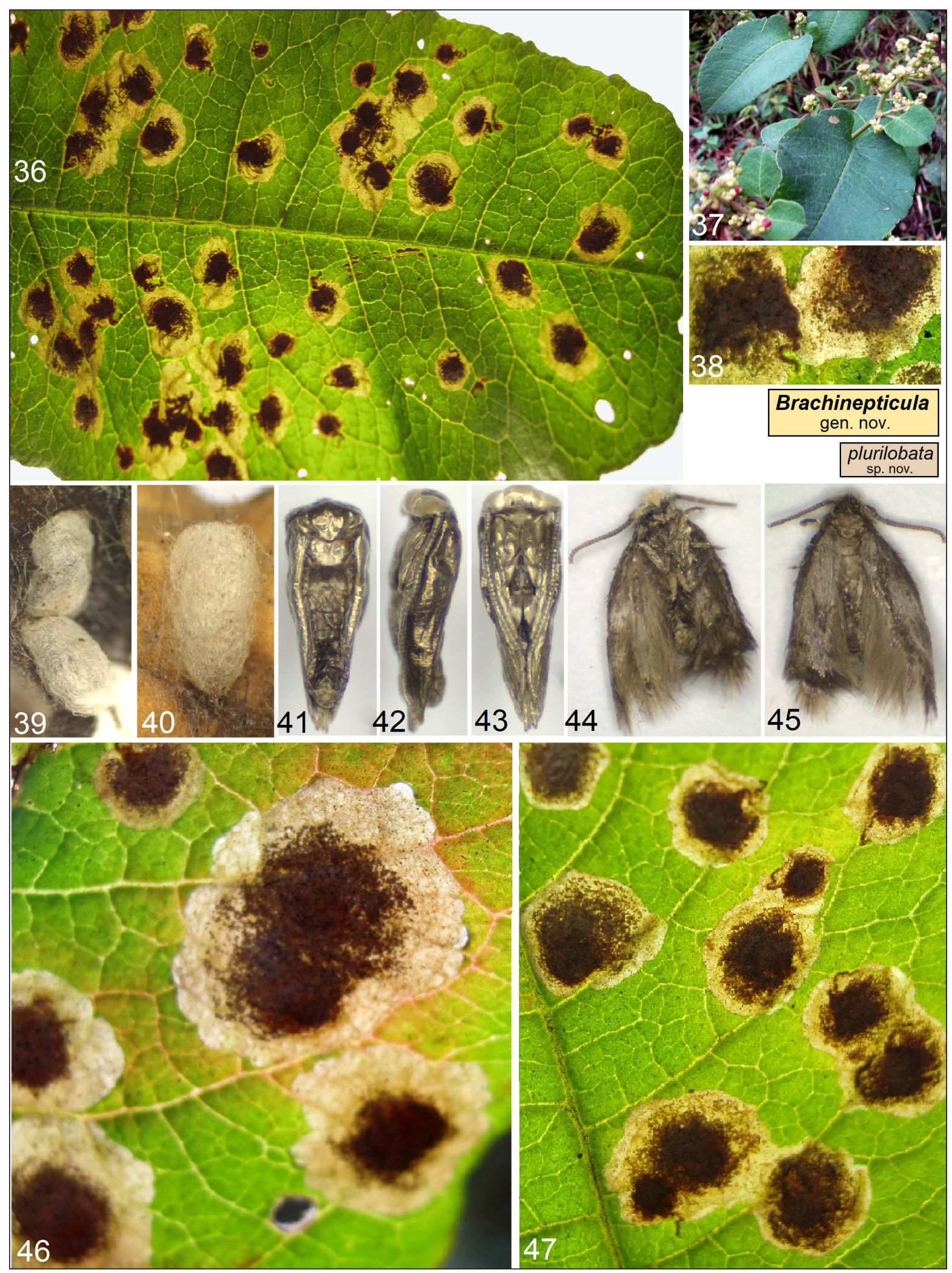

Figs. 36-47. Bionomics of Brachinepticula plurilobata Diškus \& Stonis, sp. nov. 36, 38 - leaf mines, Ecuador, 24 km NW Alóag, $0^{\circ} 27^{\prime} 07^{\prime \prime}$ S, 78 41'00”W, 2720 m, field card no. 4814; 37 - host plant, Muehlenbeckia sp.; 39, 40 - cocoons; $41-43$ - pupae; 44, 45 - adults; 46,47 - leaf mines, field card no. 4814 


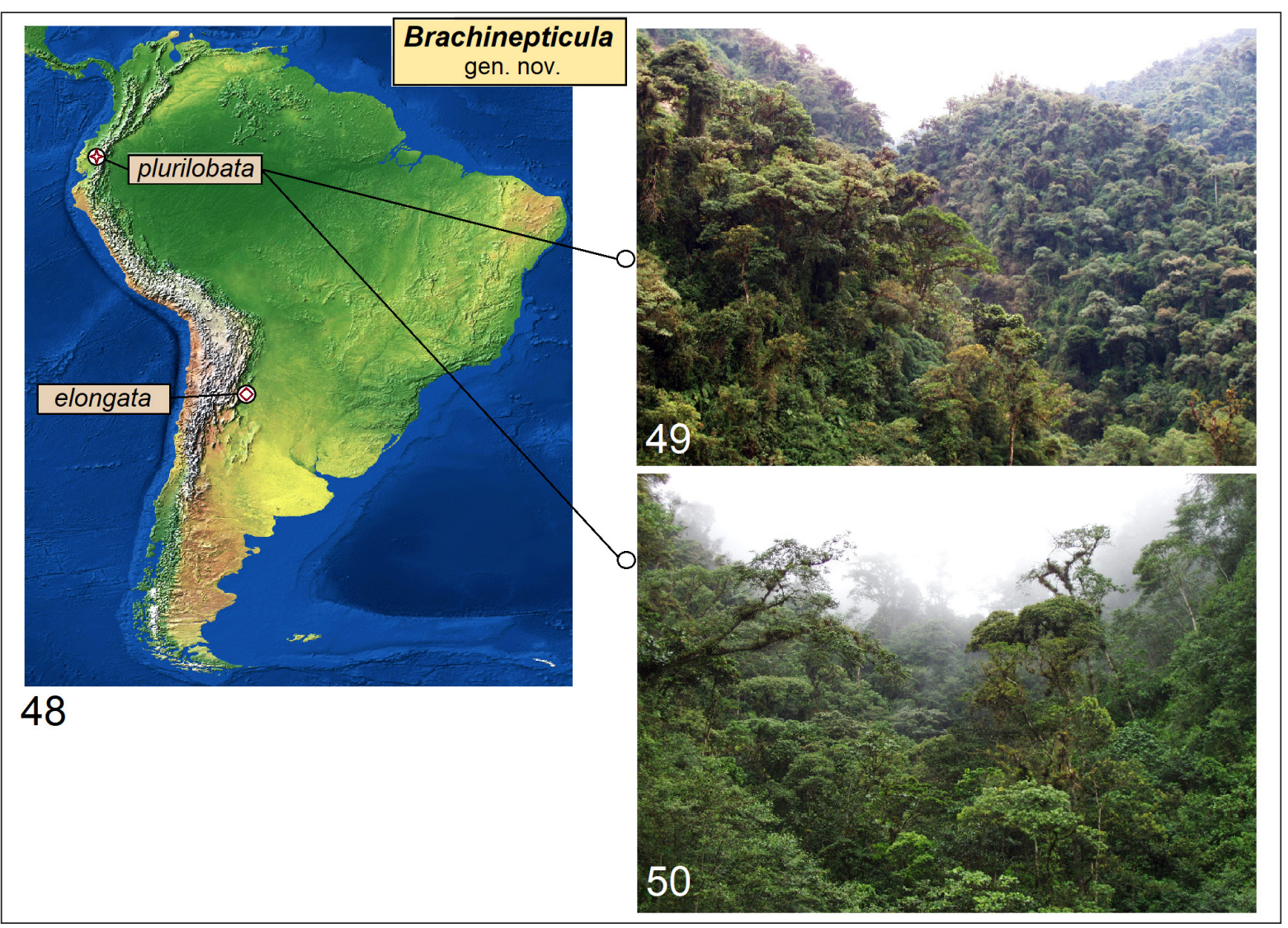

Figs. 48-50. Distribution of Brachinepticula elongata Remeikis \& Stonis, sp. nov. and B. plurilobata Diškus \& Stonis, sp. nov. 48 - map (courtesy of T. Patterson, USA); 49, 50 - habitat of B. plurilobata, 24 km NW Alóag, Ecuador

likely M. tiliifolia Wedd. However, the identity of the host plant should be treated with caution because it is based on photographed plant samples. Leaf mine starts as a short, but very slender gallery; later on it develops to a blotch with black frass accumulated in the centre of the blotch (Fig. 46). Exit slit on upper side of the leaf. Cocoon outside the mine (in forest litter), brownish cream to cream; length $2.8-3.3 \mathrm{~mm}$, maximal width $1.5-1.8 \mathrm{~mm}$. Pupa illustrated in Figs. 4143. Adults (Figs. 44-45) fly in late January - early February.

Distribution (Fig. 48). This species occurs on the western slopes of the equatorial Andes of Ecuador (Pichincha Province) at an altitude of about $2700 \mathrm{~m}$.

Etymology. The species name is derived from the Latin plures (meaning most, many, or several) and lobatus (meaning lobed) in reference to the lobate valva, juxta, and pseudoanellus of the male genitalia.

\section{ANNOTATED CATALOGUE OF RELATED GENERA}

Recent on-going fieldwork in South America, an area historically poorly surveyed for leaf-mining nepticulids, has provided additional material for morphological study, and has broadened our knowledge about distributions and biological information. Based on these new observations, we realized that a new taxonomic concept for the genera within the "Enteucha assemblage" was needed. Also, recent molecular results showed that its internal classification is still in flux. A new taxon from the Andes in South America required that we re-visit and re-evaluate morphological characters and their distribution within this assemblage. We make note that the reinforced cathrema in the phallus, shared by Manoneura and the new genus, Brachinepticula, occurs in tandem with a vesica without cornuti, a condition not found in other Nepticulidae. Its significance 
remains to be discovered. We could not justify inclusion of this new taxon into the existing genera and therefore described the new genus, Brachinepticula. We continue to expand our biological discoveries, specifically on the biology of two Brachinepticula species, and provide an Annotated Catalogue to summarize our findings in other closely related genera in the "Enteucha assemblage". We expect that future biological research will provide more clarity to the knowledge about, and relationhips among, these beautiful and biologically interesting moths.

Genus Johanssoniella Koçak, 1981 (Fig. 1) (status restored)

Type species: Nepticula acetosae Stainton, 1854: 303.

Johanssonia Borkowski, 1972: 702-705.

Johanssoniella Koçak, 1981: 99 (replacement name for Johanssonia Borkowski).

Discussion. The taxonomic status is restored. Any other solution, i.e., placing it within the highly apomorphic Enteucha Meyrick or other genus, seems impossible. At a glance, Johanssoniella may seem to lack apomorphies, but we found the triangular uncus and distinct triangular valva with long apical process supports the taxon. We expect that more apomorphies for Johanssoniella may be found in the future. The diagnostics of the genus is straightfoward.

From Brachinepticula gen. nov. (Fig. 2), the genus differs in the indistinctive or stickshaped cathrema (with long lateral processes in Brachinepticula), absent or very weakly developed juxta and pseudoanellus, triangular uncus, and the absence of vaginal sclerites in the female genitalia.

From Enteucha Meyrick (Fig. 3), the genus differs in the simple, undivided valva, the presence of a distinct triangular uncus (fully or partially reduced in Enteucha), gnathos with a stout, caudal process, usually rounded or slightly lobate vinculum (mostly triangular in Enteucha), and the forewing venation with a preserved Rs4 (reduced in Enteucha).

From Manoneura Davis (Fig. 4), the genus differs in the triangular uncus, gnathos with a stout caudal process, simple, triangular valva, short ba- sal process of valva, the absence of thickened apodeme of vinculum, indistinctive or stick-shaped cathrema, and the phallus without carinae.

Johanssoniella acetosae (Stainton, 1854) (Figs. 51-58)

Nepticula acetosae Stainton, 1854: 303.

Nepticula acetosella Doubleday, 1859: 36.

Nepticula arifoliella Klimesch, 1940: 92.

Stigmella acetosae (Stainton), Beirne, 1945: 200.

Johanssonia acetosae (Stainton), Borkowski, 1972: 702; Scoble, 1983: 15, 16.

Johanssoniella acetosae (Stainton), Koçak, 1981: 99.

Stigmella arifoliella (Klimesch) Hering, 1957: 912.

Enteucha acetosae (Stainton), Emmet, 1976: 266; van Nieukerken, 1986a: 54; Johansson et al., 1990:138, 139; Puplesis, 1994: 57; Diškus \& Puplesis, 2003: 321; van Nieukerken et al., 2016a: 103.

Host plants. Rumex acetosa L., R. acetosella L., R. arifolius All (Polygonaceae).

Distribution. Europe (except southern and northern regions): from Ireland, Sweden and Estonia to Slovenia and Ukraine.

Discussion. Two distinctly different forms of adults were reported (see Johansson et al., 1990: 139): a smaller and paler form from Western Europe ("true" J. acetosae), and a larger and darker form, with distinct purple iridescence, feeding on Rumex arifolius predominantly from Germany and alpine localities (previously described as a separate species arifoliella). Recently we discovered both forms occurring side by side in Lithuania, but the larger and darker form in the country prevails. There is still a slim chance that the forms may represent two different species; more research is still needed.

In the course of our study (see Figs. 51-58), we made some discoveries about the morphological characters of Johanssoniella acetosae, specifically the male genitalia with variously developed juxta (Figs. 1, 52, 57) and pseudoanellus (Figs. 55, 57, 58). The latter was previously unknown; it is variously expressed from specimen to specimen even from the same reared sample, but visible only in stained slides with 


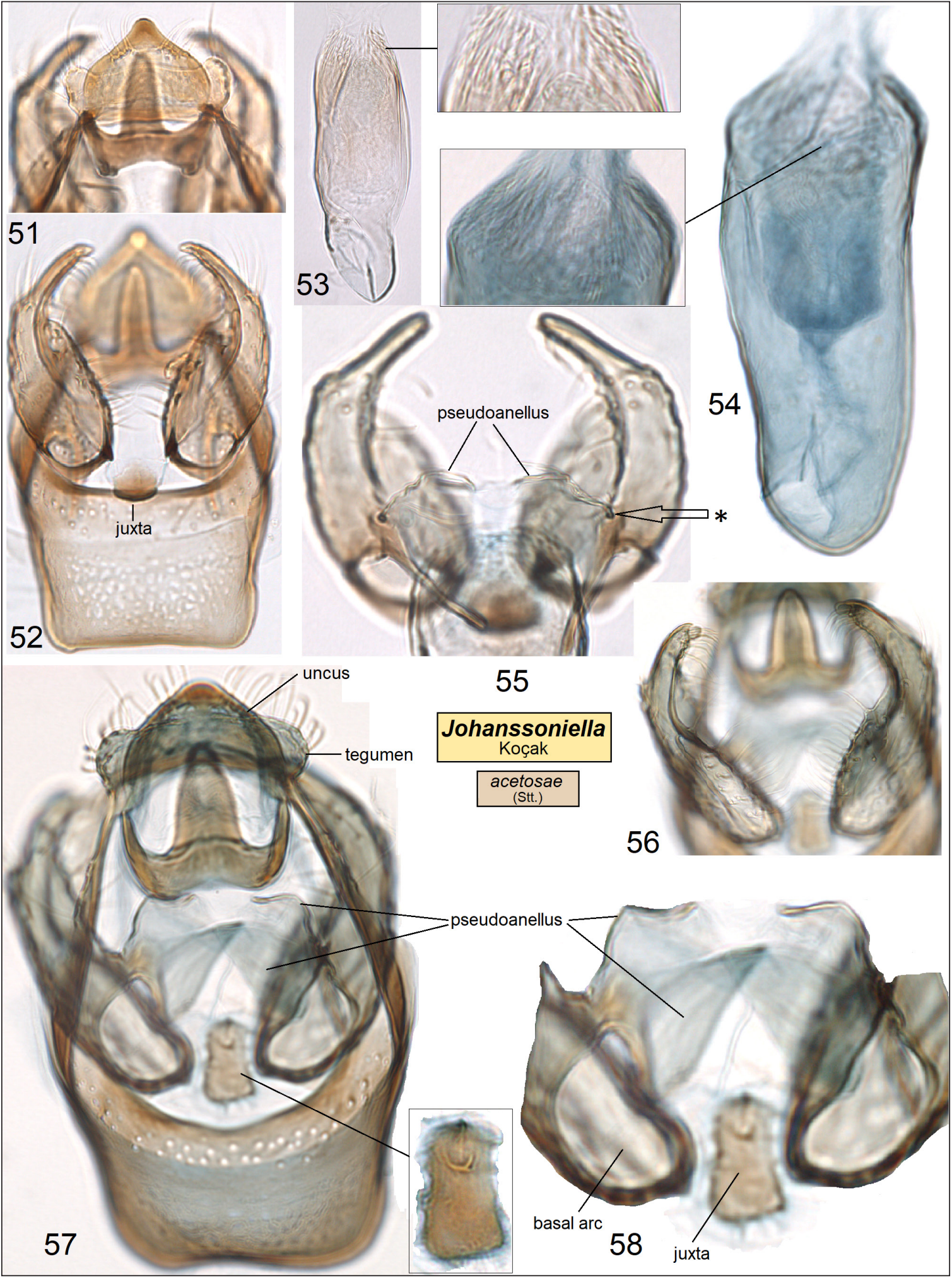

Figs. 51-58. Re-examination of Johanssoniella acetosae (Stt), the type species of the genus Johanssoniella Koçak., the "larger and darker form" (see Discussion on the species), collected in Trakai, Lithuania, $54^{\circ} 38^{\prime} 20^{\prime \prime} \mathrm{N}, 24^{\circ} 57^{\prime} 29^{\prime \prime} \mathrm{E}, 150 \mathrm{~m}$, on Rumex acetosa L., 18.vi.2000, field card no. 4635. 51, 52 - capsule with phallus removed, slide no. AD903; 53 - same, phallus; 54 - phallus, slide no. AD907; 55 - pseudoanellus, slide no. AD904; 56 - valvae, slide no. 907; 57, 58 - pseudoanellus, slide no. AD907 (LEU) 
slightly ventrally turned genitalia. The pseudoanellus and varied juxta was confirmed for both forms of $J$. acetosae collected in Lithuania.

Johanssoniella sp. (undescribed species from Japan)

Eneucha spec., van Nieukerken, 1986a: 53, 54.

Discussion. The male genitalia of an undescribed species from Japan were illustrated by van Nieukerken, 1986a: Figs. 99-101. This new, but not yet described species, exhibits a striking similarity of the male genitalia to those of the probably very closely related J. acetosae.

Johanssoniella hilli (Puplesis \& Robinson, 2000) comb. nov.

Enteucha hilli Puplesis \& Robinson, 2000: 19, 20.

Enteucha hilli Puplesis \& Robinson, in Puplesis et al., 2002b: 64; Diškus \& Puplesis, 2003: 321; van Nieukerken et al., 2016a: 103.

Host plant. Unknown.

Distribution. Central America: Belize (rainforest).

Discussion. Illustrated in Puplesis \& Robinson, 2000: Figs. 8, 69, 70. This remarkable, relatively large $(7.4 \mathrm{~mm}$ in wingspan) species is characterized by the unicolorous forewing coarsely speckled with brown scales, distinctive, practically unpaired collar comprised of wide lamellar scales, unusually large apical process of valva, narrowed ventral plate of vinculum, and the chitinized cathrema in the male genitalia; conuti in the phallus absent.

Johanssoniella contracolorea (Puplesis \& Robinson, 2000) com. nov.

Enteucha contracolorea Puplesis \& Robinson, 2000: 20.

Enteucha hilli Puplesis \& Robinson, in $\mathrm{Pu}-$ plesis et al., 2002b: 64; Diškus \& Puplesis, 2003: 321; van Nieukerken et al., 2016a: 103.

Host plant. Unknown.

Distribution. Central America: Belize (rainforest).

Discussion. Illustrated in Puplesis \& Robinson, 2000: Figs. 9, 71-74. This distinct species is characterized by the dark brown collar, large and unusually elongated scape, smooth-scaled, brown forewing with golden gloss and some blue iridesncence, highly contrasting fringe, and the peculiar uncus in a shape of inverted $\mathrm{Y}$ in the male genitalia; cathrema very simple, cornuti absent.

Johanssoniella diplocosma (Meyrick, 1921) (Figs. 59-70) comb. nov.

Nepticula diplocosma Meyrick, 1921: 410, 411.

Enteucha diplocosma (Meyrick), in Diškus \& Puplesis, 2003: 321; van Nieukerken et al., 2016a: 103.

Host plant. Persicaria amplexicaulis (D. Don) Ronse Decraene (syn. Bistorta amplexicaulis (D. Don) Greene), Polygoncaceae.

Distribution. India: Assam (type locality) and Uttarakhand (the Himalayas, at an elevation of about $2200 \mathrm{~m}$ ) (Figs. 64, 65).

Discussion. The species was described in 1921 on the basis of a single male specimen deposited at the BMNH. Externally it can be recognized by the presence of two golden glossy fasciae on a brown (or purplish brown) forewing. We compared the male genitalia of the old specimen (the holotype, slide 25652) with the male genitalia of two recently reared male pupae from Uttarakhand, India (ZIN; see Figs. 59-63); the Himalayan specimens (mature pupae) appear to be conspecific with Meyrick's holotype; it allows us to name the host plant (see Figs. 66-68) and document the leaf mines of J. diplocosma (see Figs. 69, 70) for the first time. We also added new distribution data (Fig. 65) and updated the information of mining (August) and fly period (June and August - early September). The addition is based on the following new material examined: $2 \widehat{~}$ (from mature pupae, no pinned adults preserved), India, the Himalayas, Uttarakhand, Tehri Garhwal District, Dhanaulti, $30^{\circ} 25^{\prime} 11^{\prime \prime} \mathrm{N}, 78^{\circ} 15^{\prime} 37^{\prime \prime} \mathrm{E}$, elevation $2200 \mathrm{~m}$, mining larvae on Persicaria amplexicaulis (Polygonaceae), 18.viii.2010, field card no. 5003, leg. A. Diškus and A. Navickaitè, genitalia

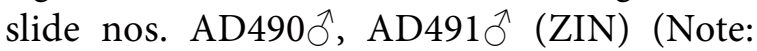
the studied type with the label "Shillong, Assam, TBF 6.19", genitalia slide no. 25652 is deposited in the BMNH).

Johanssoniella sp. (undescribed species from Japan)

Eneucha spec., van Nieukerken, 1986a: 53, 54. 


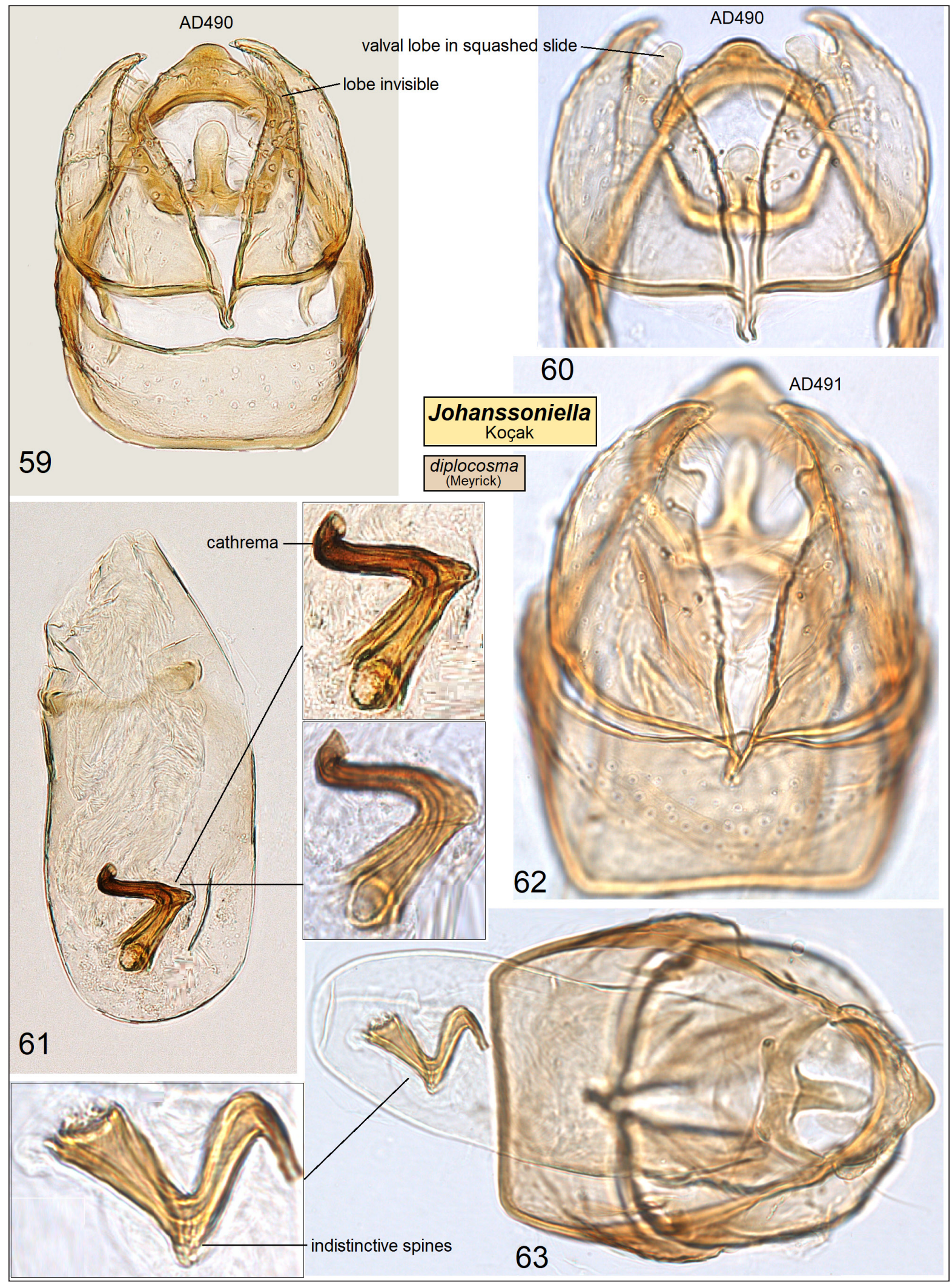

Figs. 59-63. Male genitalia of Johanssoniella diplocosma (Meyrick), the Himalaya, Uttarakhand, Dhanaulti, $30^{\circ} 25^{\prime} 11^{\prime \prime} \mathrm{N}, 78^{\circ} 15^{\prime} 37^{\prime \prime} \mathrm{E}, 2200 \mathrm{~m}$. 59 - capsule, freshly made slide AD490; 60 - same, dry slide; 61 - same, phallus; 62 - capsule, slide AD491; 63 - capsule with phallus, slide AD491 (ZIN) 


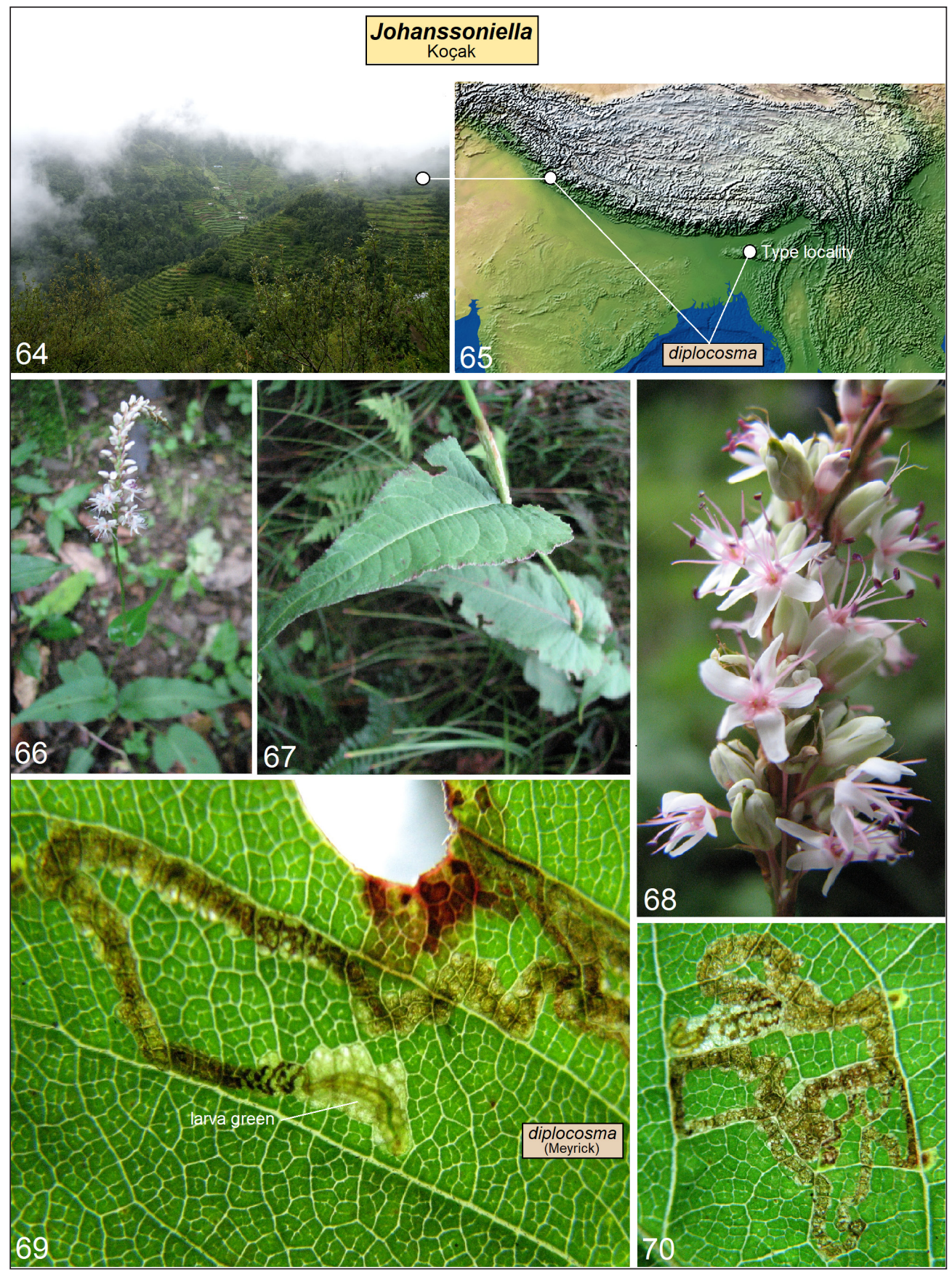

Figs. 64-70. Distribution and bionomics of Johanssoniella diplocosma (Meyrick).

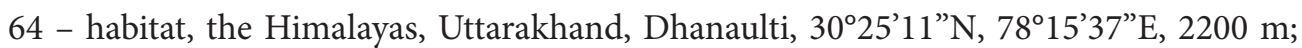
distribution map; 66-68 - host plant, Persicaria amplexicaulis; 69, 70 - leaf mines

Discussion. The male genitalia of an undescribed species from Japan were illustrated by van Nieukerken, 1986a: Figs. 96-98. This new, but not yet described species, exhibits striking similarity of the male genitalia to those of the probably very closely related diplocosma.
Johanssoniella acuta (Puplesis \& Diškus, 2002) comb. nov.

Enteucha acuta Puplesis \& Diškus, 2002a: 21, 22.

Enteucha acuta Puplesis \& Diškus, in Puplesis et al., 2002a: 21-22, Figs. 4, 26-28; 2002b: 
64; Diškus \& Puplesis, 2003: 321; van Nieukerken et al., 2016a: 103.

Host plant. Unknown.

Distribution. Ecuador (Amazon rainforest).

Discussion. Illustrated in Puplesis et al. 2002a: Figs. 4, 26-28. This distinctive species from the Amazon Basin markedly differs from other species in the slender, curved valva and large, plate-like pseudoanellus; phallus probably with a large horn-like cathrema, not a large cornutus as it was reported earlier $(\mathrm{Pu}-$ plesis et al., 2002a); however, the morphology of the phallus was not re-examined by us. Externally, J. acuta is characterized by the silvery shiny fascia on the dark colour of the forewing.

\section{Species with provisional (uncertain) place- ment in Johanssoniella}

Johanssoniella bina Remeikis \& Stonis, sp. nov. (Figs. 71-76)

Type material. Holotype: $\widehat{\partial}$, Argentina, Neuquen, Piedro del Aguila, 23.xii.1978, Mision Cientifica Danesa (leg. E. S. Nielsen et al.), genitalia slide no. RA523 $\hat{\partial}$ (ZMUC). Paratype: $1 \hat{\jmath}$, Neuquen, Rio Limay, Arroyito, 17.xi.1978, Mision Cientifica Danesa, (leg. E. S. Nielsen et al.), genitalia slide no. RA522 $\bigcirc$ (ZMUC).

Diagnosis. The combination of a sparsely speckled forewing, inverted V-shaped gnathos, trapezoid vinculum and a large, and distinctive cathrema in the male genitalia distinguishes E. bina sp. nov. from all currently known nepticulid species, including all Johanssoniella (also see Discussion).

Male (Figs. 71, 72). Forewing length 2.1$2.7 \mathrm{~mm}$; wingspan $4.6-5.9 \mathrm{~mm}$. Head: palpi golden cream to brownish-cream, distally greybrown on upper side; frontal tuft brown on vertex, cream on frons; collar comprised of piliform scales, cream; scape cream; antenna half the length of forewing; flagellum with about 45 segments, pale brownish-cream on upper side and underside. Thorax, tegula and forewing cream with some golden gloss, sparsely speckled with pale brown and brown scales; fringe cream; underside of forewing brownish-yellow, without spots or androconia. Hindwing cream on upper side and underside, without spots or androconia; fringe cream. Legs golden cream to brownish-cream; foreleg darkened distally with brown scales on upper side. Abdomen grey cream on upper side, grey on underside; anal tufts short, cream; genital plates grey.

Female. Unknown.

Male genitalia (Figs. 73-76). Capsule about $350 \mu \mathrm{m}$ long. Uncus widely rounded, with a very short caudal process (Fig. 73). Gnathos inverted V-shaped, with widely rounded caudal element (Fig. 73). Valva with a large apical process. Transtilla absent. Vinculum wide, without lateral lobes. Phallus (Figs. 74-76) $370 \mu \mathrm{m}$ long, 130-140 $\mu \mathrm{m}$ wide, with a large, binary cathrema and numerous indistinctive, spine-like cornuti (Fig. 76).

Bionomics. Host plant unknown. Adults fly in November and December.

Distribution. This species occurs in the southern Andes (Argentina: Neuquen).

Etymology. The species name is derived from Latin binus (two at a time, binary) in reference to the binary cathrema in the male genitalia.

Discussion. The taxonomic position of J. bina is uncertain and, therefore, provisional. This new species is placed in Johanssoniella because of the general similarity of the male genital capsule to Johanssoniella. However, this species possesses an odd, binary cathrema in the phallus and, in contrast to other Johanssoniella or related taxa, a collar comprised of piliform (not lamellar) scales. In the future, when wing venation or molecular data becomes available, the taxonomic position of bina may be refined.

Johanssoniella terricula (Puplesis \& Robinson, 2000) comb. nov.

Enteucha terricula Puplesis \& Robinson, 2000: 20, 21.

Enteucha terricula Puplesis \& Robinson, in Puplesis et al., 2002b: 64; Diškus \& Puplesis, 2003: 321; van Nieukerken et al., 2016a: 103.

Host plant. Unknown.

Distribution. Central Andes (Peru: Department Puno).

Discussion. The placement of J. terricula in Johanssoniella is very uncertain and, therefore, only provisional. There are only two characters 


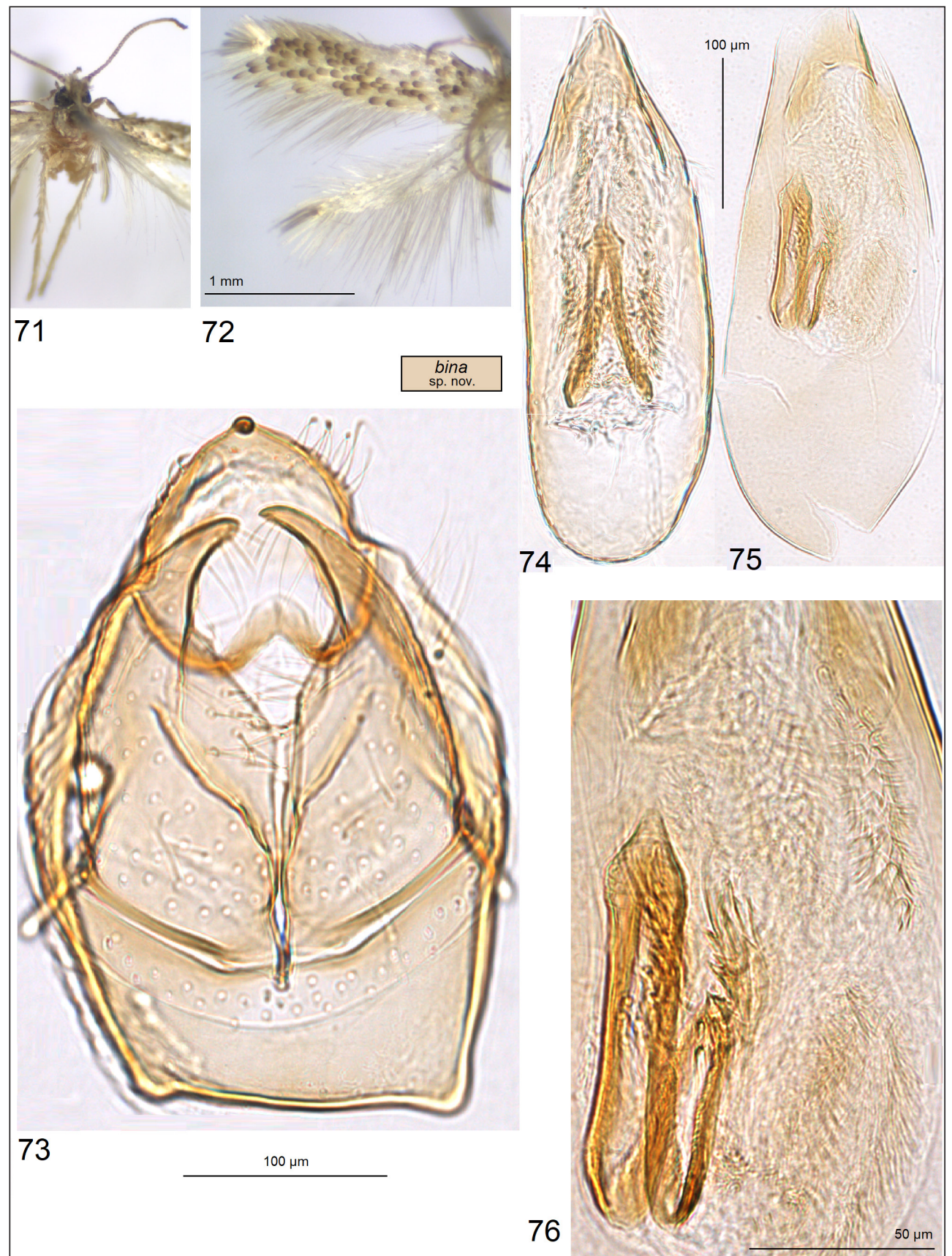

Figs. 71-76. Johanssoniella bina Remeikis \& Stonis, sp. nov., Argentina, Neuquen. 71 - fragment of male adult, paratype; 72 - male adult, holotype; 73 - capsule with phallus removed, holotype, slide no. RA523; 74 - phallus, holotype, slide no. RA523; 75, 76 - same, paratype, slide RA522 (ZMUC)

of the male genitalia which $J$. terricula shares with other Johanssoniella: the triangular uncus and indistinctive cathrema. This new species is placed in Johanssoniella mostly because of the lack of apomorphies characteristic of other described genera.
Genus Brachinepticula Stonis \& Diškus, gen. nov. (described above) (Fig. 2)

Type species Brachinepticula plurilobata Diškus \& Stonis, sp. nov.

Discussion. Along with the unusually reinforced cathrema or the vaginal sclerites in 
the female genitalia, the presence of pseudoanellus or bifid juxta seem to be very strong apomorphies (Fig. 2). However, our morphological studies of the European Johanssoniella acetosae unexpectedly revealed the presence of a pseudoanellus and juxta, though very weakly developed, in the genus Johanssoniella as well. It may indicate a possible relationship between Brachinepticula with Johanssoniella. Nevertheless, Brachinepticula is a very distinctive and highly apomorphic genus (see the legend of Fig. 2). Diagnostics of the taxon is provided above, in the description of Brachinepticula.

Brachinepticula elongata Remeikis \& Stonis, sp. nov. (described above) (Figs. 5, 6, 12-17)

Host plant. Unknown.

Distribution. Argentina (the Jungas biogeographical province) (Fig. 48).

Brachinepticula plurilobata Diškus \& Stonis, sp. nov. (described above) (Figs. 7-11, 18-50)

Host plant. Belongs to the Polygonaceae family; probably Muehlenbeckia Meisn.: M. tamnifolia (Kunth) Meisn., or, most likely, M. tiliifolia Wedd., but the identification needs to be confirmed (Figs. 36-38, 46, 47).

Distribution. Ecuador (Pichincha Province) (Figs. 48-50).

Genus Enteucha Meyrick, 1915 (Fig. 3)

Enteucha Meyrick, 1915: 241.

Type species: Enteucha cyanochlora Meyrick, 1915: 241.

Artaversala Davis, 1978: 219, 221.

Type species: Artaversala gilvafascia Davis, 1978: 221-223.

Discussion. From Johanssoniella Koçak (Fig. 1), the genus differs in the divided valva, reduced or partially reduced uncus (distinct, triangular in Johanssoniella), usually transverse gnathos without a stout, caudal process, triangular vinculum (rounded or slightly lobate in Johanssoniella), and the forewing venation with reduced Rs4 (preserved in Enteucha).

From Brachinepticula gen. nov. (Fig. 2), the genus differs in the cathrema without large lateral processes, divided, two-folded valva, reduced or partially reduced uncus (distinct, rounded in Brachinepticula), usually transverse gnathos without a stout caudal process, absence of pseudoanellus and juxta, reduced forewing venation (see Figs. 2 and 3), and the absence of vaginal sclerites in the female genitalia.

From Manoneura Davis (Fig. 4), the genus differs in the simple cathrema (extended, halftubular in Manoneura), usually transverse gnathos, reduced or partially reduced uncus (uncus with gnathos form a lock-shaped structure in Manoneura), absence of thickened lateral apodeme, triangular vinculum, phallus without carinae (latter strongly developed in Manoneu$\mathrm{ra}$ ), and the differently reduced forewing venation (see Figs. 3 and 4).

Enteucha cyanochlora Meyrick, 1915

Enteucha cyanochlora Meyrick, 1915: 241.

Enteucha cyanochlora Meyrick, in Davis, 1985: 142-145; van Nieukerken, 1986: 52, Figs. 87-89; Puplesis et al., 2002b: 64; Diškus \& Puplesis, 2003: 321; van Nieukerken et al., 2016: 103.

Host plant. Unknown.

Distribution. South America: Guyana (Bartica).

Enteucha gilvafascia (Davis, 1978)

Artaversala gilvafascia Davis, 1978: 221-223.

Enteucha gilvafascia (Davis), in van Nieukerken, 1986a: 52, Figs. 90-92; Puplesis et al., 2002b: 64; Diškus \& Puplesis, 2003: 321; van Nieukerken et al., 2016a: 103.

Host plant. Coccoloba uvifera (L.) L., Polygonaceae.

Distribution. USA: Florida (Davis, 1978; 1984) and Cuba (Núñez Aguila \& Barro Cañamero, 2012).

Enteucha snaddoni Puplesis \& Robinson, 2000

Enteucha snaddoni Puplesis \& Robinson, 2000: 21, 22.

Enteucha snaddoni Puplesis \& Robinson, in Puplesis et al., 2002b: 64; Diškus \& Puplesis, 2003: 321; van Nieukerken et al., 2016a: 103.

Host plant. Unknown.

Distribution. Central America: Belize (rainforest).

Discussion. The species is illustrated in $\mathrm{Pu}-$ plesis \& Robinson, 2002: Figs. 10, 75-79. This species from the Belize rainforest differs from other species by the partially reduced, almost 
membranous, but lobe-like uncus and by the combination of a large triangular vinculum, very long and inwardly bent apical process of the valva, and a distinctly transverse gnathos.

Genus Manoneura Davis, 1979 (Figs. 4, 77-101)

Manoneura Davis, 1979: 276. Replacement name for Oligoneura Davis, nec Bigot, 1878.
Type species: Oligoneura basidactyla Davis, 1978: 218, 219.

Oligoneura Davis, 1978: 217, 218.

Type species: Oligoneura basidactyla Davis, 1978: 218, 219.

Discussion. From Johanssoniella Koçak (Fig. 1), the genus differs in the unique uncus and gnathos in the form of lock-shaped

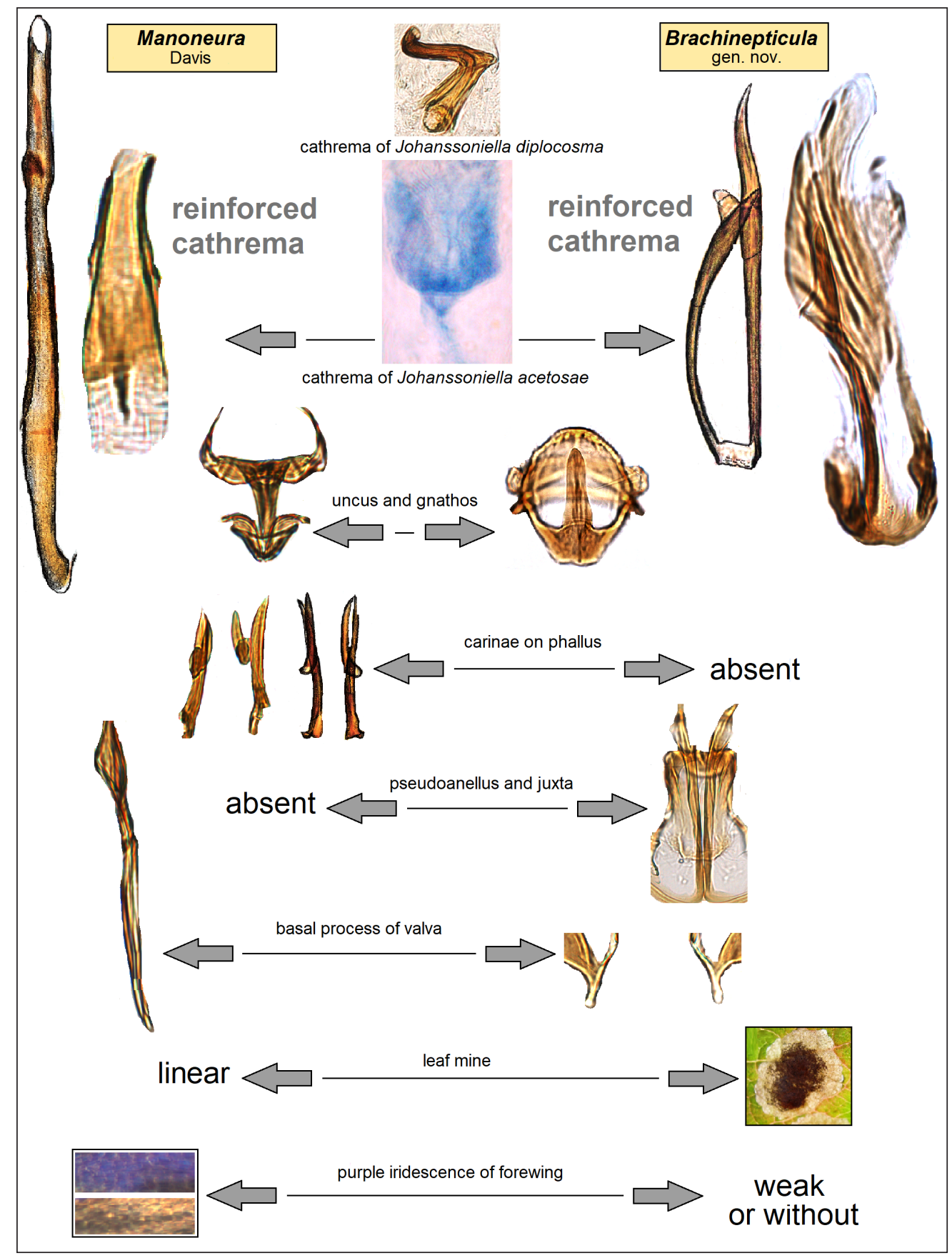

Fig. 77. Differentiation of Manoneura Davis and Brachinepticula gen. nov. 


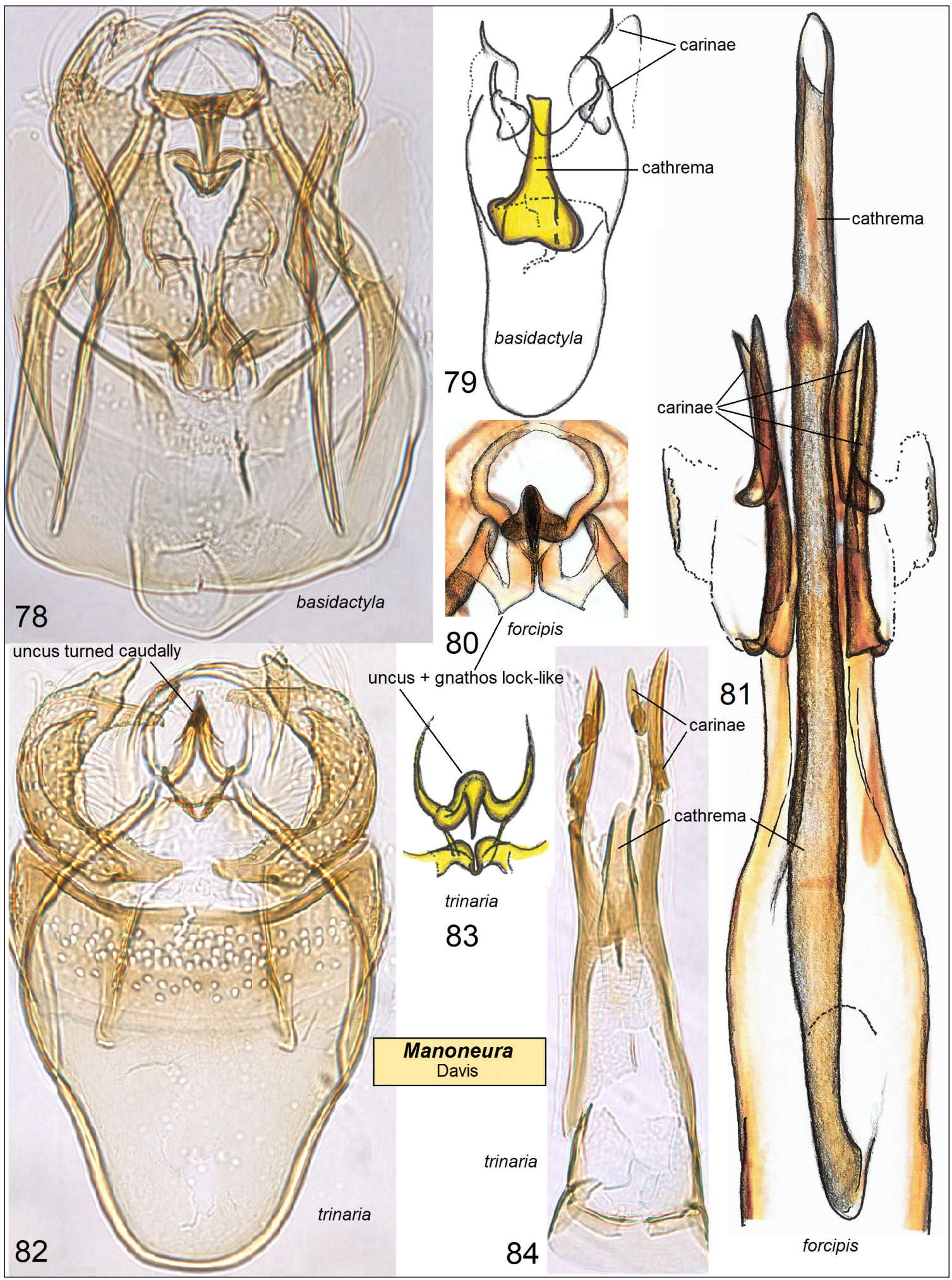

Figs. 78-84. Manoneura Davis, male genitalia. 78 - M. basidactyla (Davis), slide no. Diškus002 USNM, capsule with phallus, Dominica; 79, same, slide no. 29120 BMNH, phallus, Belize; 80 - M. forcipis Remeikis \& Stonis, slide no. RA552 ZMUC, uncus and gnathos, Peru; 81, same, cathrema and carinae; 82 - M. trinaria Puplesis \& Robinson, slide no. Diškus003 USNM, capsule with phallus removed, Venezuela; 83 - same, uncus and gnathos; 84 - same, phallus 


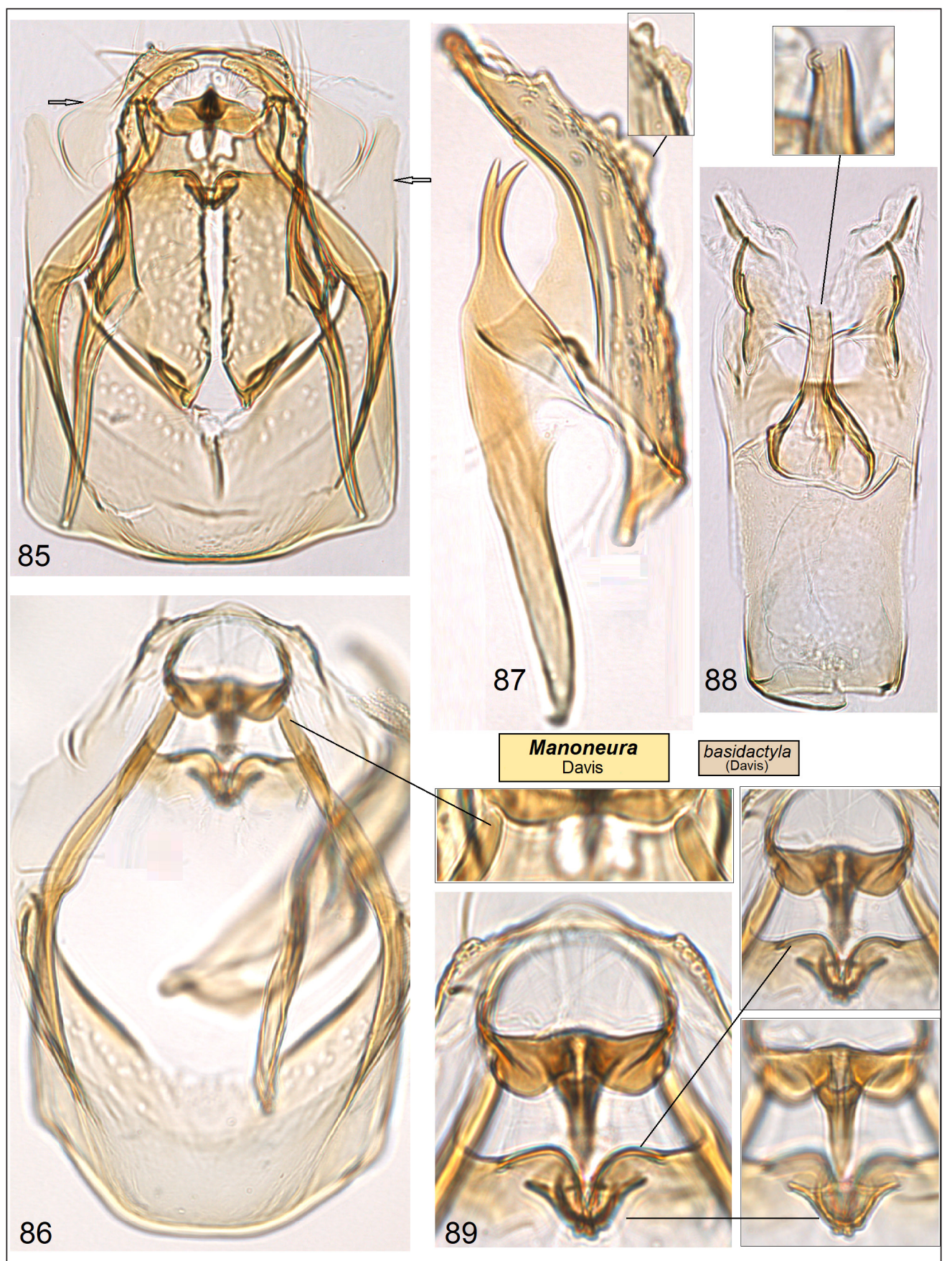

Figs. 85-89. Documentation of male genitalia of Manoneura basidactyla (Davis) from the Amazon rainforest, Ecuador, Napo Region. 85 - capsule with phallus removed, slide no. AD327; 86 - lateral apodemes of vinculum, slide no. AD905; 87 - valva, lateral view, slide no. AD905; 88 - phallus, slide no. AD327 ; 89 - uncus and gnathos, slide no. AD905 (ZMUC)

structure (uncus wide, triangular in Johanssoniella, gnathos with a stout caudal process), very long basal process of valva (short in Johanssoniella), the presence of a thickened apodeme of vinculum (absent in Johanssoniella), valva with a dor- sal process (absent in Johanssoniella), phallus with distinct carinae (absent in Johanssoniella), greatly extended, half-tubular cathrema, and the greatly reduced forewing venation (see Figs. 1 and 4). 


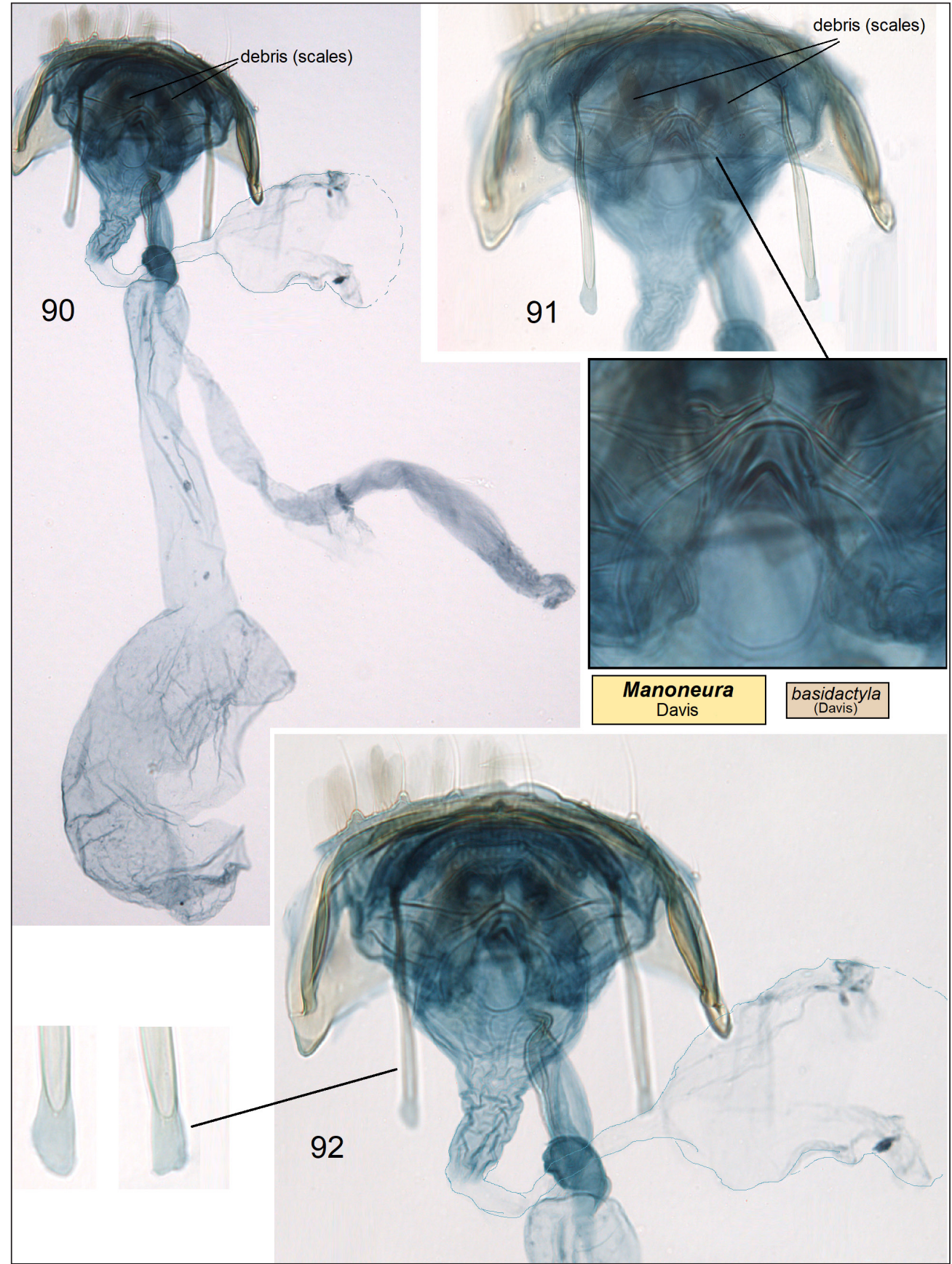

Figs. 90-92. Documentation of female genitalia of Manoneura basidactyla (Davis) from the Amazon rainforest, Ecuador, Napo Region, genitalia slide no. AD326 (ZMUC). 90 - general view; 91, 92 - apophyses

From Brachinepticula gen. nov. (Fig. 2), the genus differs in the absence of pseudoanellus and juxta, the unique uncus and gnathos in the form of a moveable lock-shaped structure (uncus wide, rounded in Brachinepticula, gnathos with a stout caudal process),very long basal process of valva (short in Brachinepticula), the presence of a thickened apodeme of vinculum (absent in Brachinepticula), phallus with distinct carinae (absent in Brachinepticula), half-tubular cathrema, and the greatly reduced forewing venation (see Figs. 2 and 4).

From Enteucha Meyrick (Fig. 3), the genus differs in the unique half-tubular cathrema, unique 
uncus and gnathos in the form of lock-shaped structure (uncus reduced or partially reduced in Enteucha), presence of a thickened lateral apodeme (absent in Enteucha), very wide vinculum (triangular in Enteucha), phallus with distinct carinae (absent in Enteucha), and the differently reduced forewing venation (see Figs. 3 and 4).
Manoneura basidactyla (Davis, 1978) (Figs. 78, 79, 85-92, 97-101)

Oligoneura basidactyla Davis, 1978: 218, 219.

Manoneura basidactyla (Davis), in Puplesis \& Robinson, 2000: 22-23: Figs. 12, 83-85, 207; Puplesis et al., 2002b: 61, 62, Figs. 6, 9-14; Diškus \& Puplesis, 2003: 321.

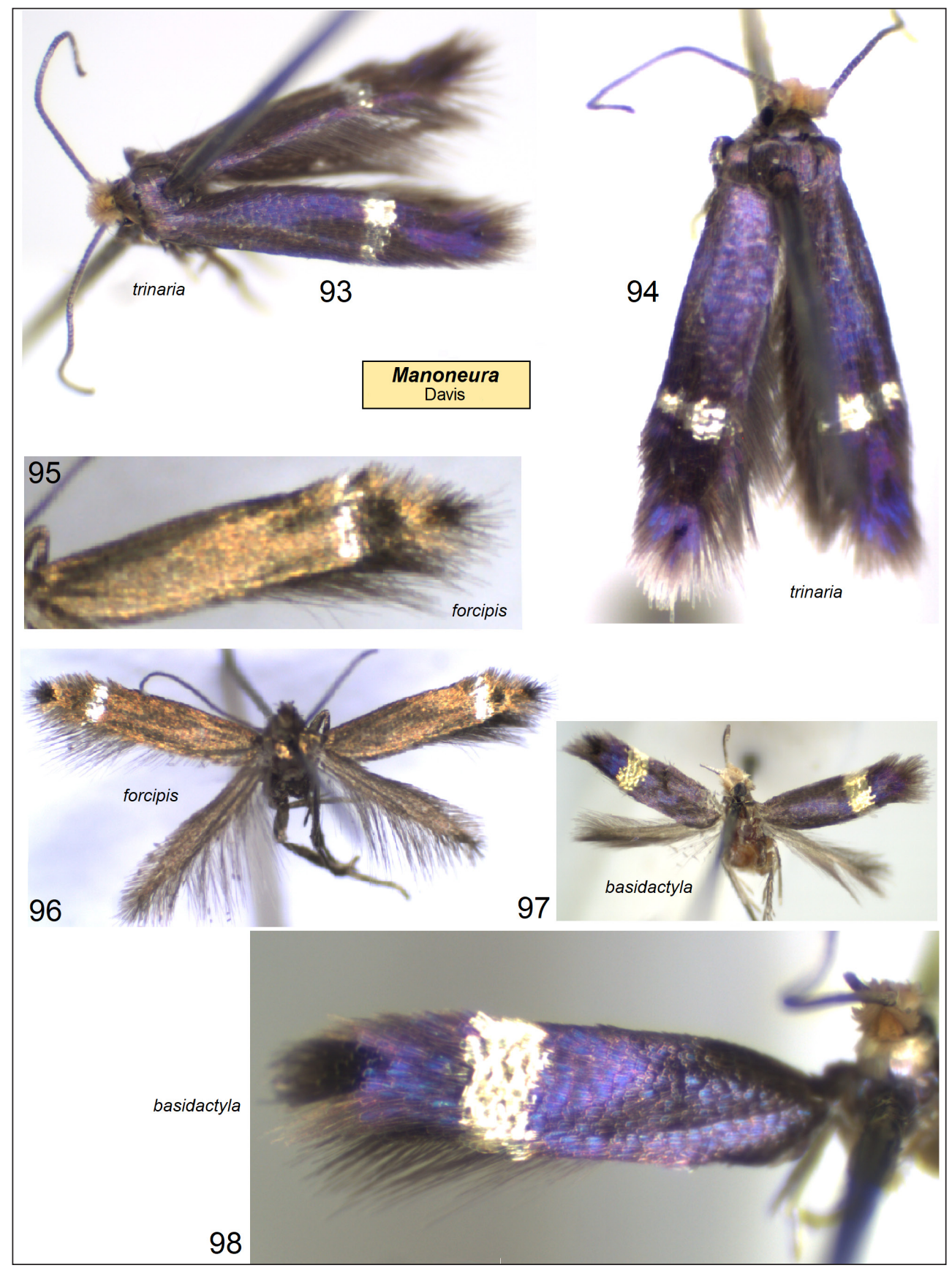

Figs. 93-98. Adults of Manoneura Davis. 93, 94 - M. trinaria Puplesis \& Robinson, Venezuela (USNM); 95, 96 - M. forcipis Remeikis \& Stonis, Peru (ZMUC); 97, 98 - M. basidactyla (Davis), Dominica (USNM) 


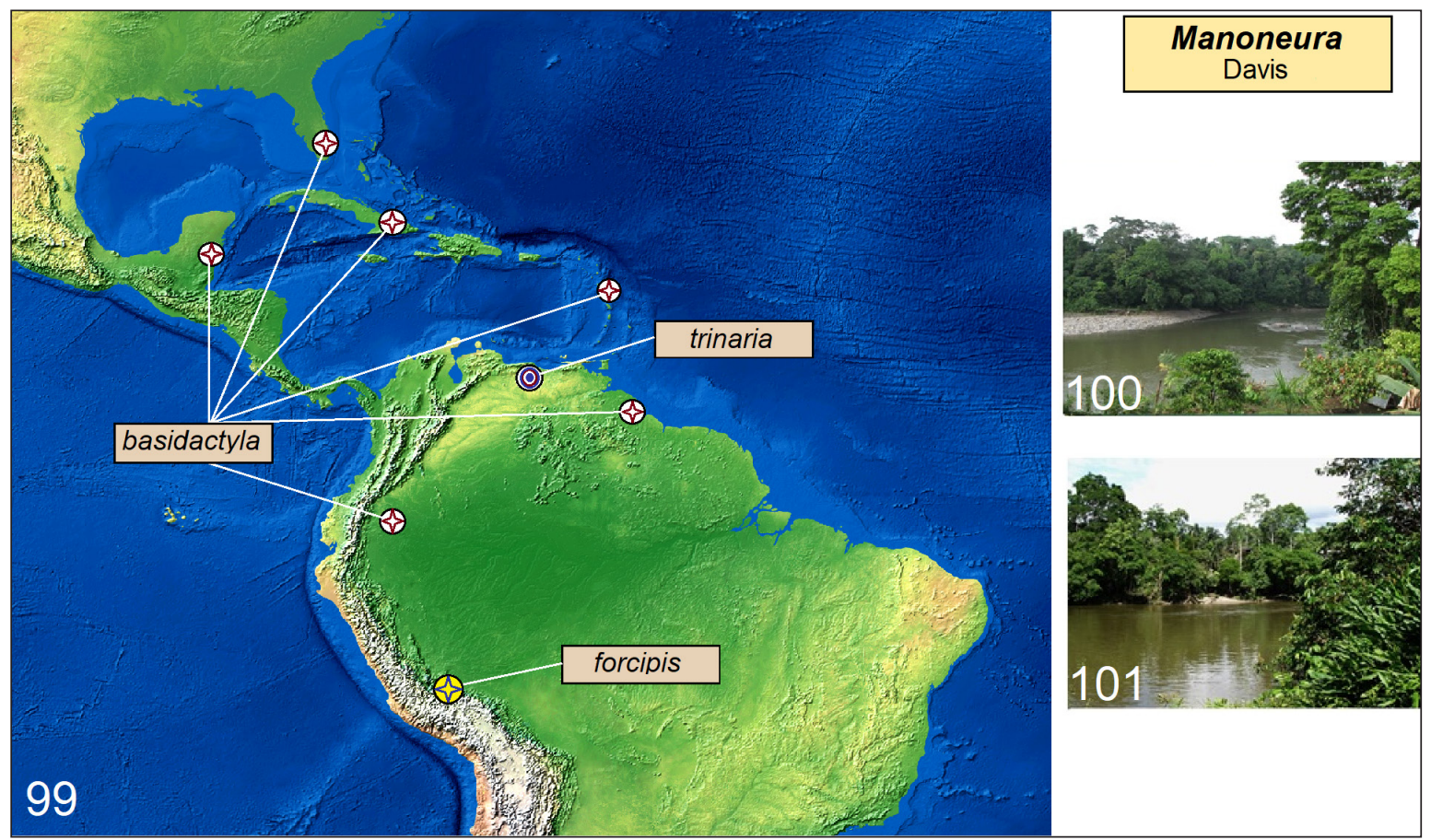

Figs. 99-101. Distribution of Manoneura (Davis). 99 - distribution map of the currently known species (courtesy of T. Patterson, USA); 100, 101, habitat of M. basidactyla (Davis), the Amazon rainforest, Napo Region, Ecuador

Enteucha basidactyla (Davis), in van Nieukerken et al., 2016a: 103.

Host plant. Coccoloba uvifera (L.) L., Polygonaceae.

Distribution. USA (Florida, Davis, 1978), Cuba (Núñez Aguila \& Barro Cañamero, 2012), Dominica (Puplesis \& Robinson, 2000), Belize (rainforest, Puplesis \& Robinson, 2000), Ecuador (Amazon Basin, Puplesis et al., 2002b), French Guiana (D. C. Lees, pers. comm.).

Discussion. Manoneura basidactyla possesses a very strong purple iridescence (lustre) on the forewing (Figs. 97, 98). This remarkable species was re-desribed and illustrated in $\mathrm{Pu}-$ plesis \& Robinson, 2000: 22-23; here we add only the data lacking in the former re-description: abdomen black to fuscous with yellowish bronzy lustre on upper side, blackish grey on underside; genital plates blackish grey to black, not contrasting with the main color of the abdomen, anal tufts grey-black, short. Here we also provide the first photographic documentation of the specimens collected in the Amazon Basin (Figs. 85-92, 97, 98) first reported by $\mathrm{Pu}-$ plesis et al. 2002b; these specimens differ very little from specimens from other localities (see Distribution).

Manoneura trinaria Puplesis \& Robinson, 2000 (Figs. 82-84 93, 94, 99)

Manoneura trinaria Puplesis \& Robinson, 2000: 23.

Manoneura trinaria Puplesis \& Robinson, in Puplesis et al., 2002b: 64; Diškus \& Puplesis, 2003: 322.

Enteucha trinaria (Puplesis \& Robinson), in van Nieukerken et al., 2016a: 103.

Host plant. Unknown.

Distribution. Venezuela (Puplesis \& Robinson, 2000).

Discussion. Manoneura trinaria possesses very strong purple iridescence on the forewing (Figs. 93, 94). Originally the species was described and illustrated in Puplesis \& Robinson, 2000: 23; Figs. 13, 86, 87. In the current paper we provide the first photographic documentation of the adult (Figs. 93, 94) and male genitalia of M. trinaria (Fig. 85-92, 97, 98); note the uncus turned caudally in Fig. 78. 
Manoneura forcipis Remeikis \& Stonis, 2017 (Figs. 80, 81, 95, 96, 99)

Manoneura forcipis Remeikis \& Stonis, in Stonis et al., 2017: 58.

Host plant. Unknown.

Distribution. Central Andes (Peru: Apurimac Department) (Stonis et al., 2017).

Discussion. This distinctive, highly apomorphic species was recently described and illustrated by Stonis et al., 2017: Figs. 2, 9, 33, 95, 96 (note the unusually extended cathrema, illustrated in Fig. 81 of this paper).

\section{A genus not discussed here, but possibly related to Enteucha Meyrick. \\ Genus Varius Scoble, 1983 \\ Varius Scoble, 1983: 14.}

Type species: Stigmella ochnicola Vári, 1955: 336, 337.

Discussion. The genus is characterized by less reduced forewing venation (see Scoble, 1983: Fig. 12), deeply divided valva, elongated cathrema, and the absence of cornuti in the male genitalia. Female genitalia without vaginal sclerites. Single known species is trophically associated with Ochnaceae.

Varius ochnicolus (Vári, 1955)

Stigmella ochnicola Vári, 1955: 336, 337.

Varius ochnicolus (Vári), in van Nieukerken et al., 2016a: 103.

Host plant. Ochna pulchra Hook., Ochnaceae (Malpighiales).

Distribution. Republic of South Africa: Gauteng (Pretoria).

\section{ACKNOWLEDGEMENTS}

We are indebted to Ole Karsholt and the late Professor Niels P. Kristensen (ZMUC) for the initial stimulus to start the Neotropical project as well as for generous support during its course and the loan of the Neotropical material. For helpful and frequent discussions on various host plants, we thank Dr. Arvind Singh (Banaras Hindu University, Varanasi, India), Dr. José Luis Fernández-Alonso (Universidad de Salamanca, Spain), Dr. Franz Starlinger (Federal Research and Training Centre for For- ests, Natural Hazards and Landscape, Vienna, Austria), Dr. Asok Ghosh (University of Burdwan, Barddhamān, India), and Dr. Nixon Cumbicus Torres (Universidad Técnica Particular de Loja, Ecuador). We are very grateful to Lauri Kaila (Finnish Museum of Natural History, University of Helsinki, Finland) for helpful discussions. This study was supported by the Research Foundation of the Lithuanian University of Educational Sciences.

Mention of trade names or commercial products in this publication is solely for the purpose of providing specific information and does not imply recommendation or endorsement by the USDA. The USDA is an equal opportunity provider and employer.

Received 2 November 2017 Accepted 12 December 2017

\section{References}

1. Beirne BP. The male genitalia of the British Stigmellidae (Nepticulidae) (Lep.). Proc R Ir Acad B. 1945; 50(9): 191-218.

2. Borkowski A. Studien an Nepticuliden (Lepidoptera). Teil IV. Bemerkungen zur Nomenclatur und Systematik der Familie Nepticulidae. Pol Pismo Entomol. 1972; 42(3): 689-709.

3. Davis DR. New leaf-mining moths of the family Nepticulidae from Florida. Fla Entomol. 1978; 61(4): 209-224.

4. Davis DR. Manoneura, a new name to replace the generic homonym Oligoneura Davis (Lepidoptera: Nepticulidae). Fla Entomol. 1979; 62(3): 276.

5. Davis DR. Nepticulidae. In: Heppner JB, editor. Atlas of Neotropical Lepidoptera. Checklist: part 1. Micropterigoidea - Immoidea. The Hague: Dr. W. Junk Publishers; 1984. xxvii, $112 \mathrm{p}$.

6. Davis DR. A re-examination of Enteucha cyanochlora Meyrick and its subsequent transfer to the Nepticulidae (Lepidoptera: Nepticuloidea). Proc Entomol Soc Wash. 1985; 87(1): 142-145. 
7. Diškus A, Puplesis R. Catalogue of the world Nepticuloidea \& Tischerioidea. In: Puplesis R, Diškus A, editors. The Nepticuloidea \& Tischerioidea (Lepidoptera) - a global review, with strategic regional revisions. Kaunas: Lutute Publishers; 2003. p. 318-436.

8. Doorenweerd C, Nieukerken EJ van, Hoare RJB. Phylogeny, classification and divergence times of pygmy leaf-mining moths (Lepidoptera: Nepticulidae): the earliest lepidopteran radiation on Angiosperms? Syst Entomol. 2016; 42(1): 267-287. doi: 10.1111/syen.12212

9. Doubleday $\mathrm{H}$. The zoologist synonymic list of British butterflies and moths, 2nd ed. London: Edward Newman; 1859. 40 p.

10. Hering EM. 1957. Bestimmungstabellen der Blattminen von Europa. The Hague: Dr. W. Junk Publishers; 1957. 1/2: 1185 p., 3: 221 p.

11. Johansson R, Nielsen ES, van Nieukerken EJ, Gustafsson B. The Nepticulidae and Opostegidae (Lepidoptera) of North West Europe. Fauna Entomol Scand. 1990; 23(1/2): 1-739.

12. Klimesch J. 1940. Beschreibung einiger neuer Nepticula-Arten (Lep., Nepticulidae). (Nept. tergestina auf Euphorbia sp., Nept. geimontani auf Geum montanum, Nept. nigrosparsella auf Quercus pubescens, Nept. arifoliella auf Rumex arifolius). Zeitschr Wr Ent - Ver. 1940; 25: 7981, 89-93.

13. Koçak AÖ. On the nomenclature of some genera of Lepidoptera. Priamus. 1981; 1: 97-109.

14. Meyrick E. Descriptions of South American Micro-Lepidoptera. Trans Entomol Soc Lond. 1915; 48(2): 201-256. http://dx.doi. org/10.1111/j.1365-2311.1915.tb02527.x

15. Meyrick E. Exotic Microlepidoptera. 1921; 2(13): 385-416.

16. van Nieukerken EJ. Systematics and phylogeny of Holarctic genera of Nepticulidae (Lepidoptera, Heteroneura: Monotrysia). Zool Verhandel. 1986a; 236: 1-93.

17. van Nieukerken EJ. A provisional phylogenetic check-list of the western Palaearctic Nepticulidae, with data on hostplants (Lepidoptera). Entomol. Scand. 1986b; 17(1): 1-27.
18. van Nieukerken EJ, Doorenweerd C, Hoare JR, Davis DR. Revised classification and catalogue of global Nepticulidae and Opostegidae (Lepidoptera, Nepticuloidea). ZooKeys. 2016; 628: 65-246.

19. Núñez Aguila R, Barro Cañamero A. A list of Cuban Lepidoptera (Arthropoda: Insecta). Zootaxa. 2012; 3384: 1-59.

20. Puplesis R. The Nepticulidae of Eastern Europe and Asia: western, central and eastern parts. Leiden: Backhuys Publishers; 1994. 552 p.

21. Puplesis R, Diškus A. The Nepticuloidea \& Tischerioidea (Lepidoptera) - a global review, with strategic regional revisions. Kaunas: Lutute Publishers; 2003. 512 p.

22. Puplesis R, Robinson GS. A review of the Central and South American Nepticulidae (Lepidoptera) with special reference to Belize. Bull Nat Hist Mus Entomol. 2000; 69(1): 3-114.

23. Puplesis R, Diškus A, Robinson GS. New Neotropical Nepticulidae (Lepidoptera) from the western Amazonian rainforest and the Andes of Ecuador. Bull Nat Hist Mus Entomol. 2002a; 71(1): 19-58.

24. Puplesis R, Diškus A, Robinson GS, Onore G. A review and checklist of the Neotropical Nepticulidae (Lepidoptera). Bull Nat Hist Mus Entomol. 2002b; 71(1): 59-76. http://dx.doi. org/10.1017/S0968045402000032

25. Regier JC, Mitter C, Zwick A, Bazinet AL, Cummings MP, Kawahara AY, Sohn JC, Zwickl DJ, Cho S, Davis DR, Baixeras J, Brown J, Parr C, Weller S, Lees DC, Mitter KT. A large-scale, higher-level, molecular phylogenetic study of the insect order Lepidoptera (Moths and Butterflies). Plos One. 2013; 8(3): e58568.

26. Schoorl JW, Nieukerken EJ van, Wilkinson C. The Stigmella oxyacanthella species group in Europe (Nepticulidae: Lepidoptera). Syst Ent. 1985; 10: 65-103. doi:10.1111/j.1365-3113.1985. tb00565.x

27. Scoble MJ. A revised cladistic classification of the Nepticulidae (Lepidoptera) with descriptions of new taxa mainly from South Africa. Transv Mus Monograph. 1983; 2: i-xi, 105 p. 
28. Stainton HT. Insecta Britannica. Lepidoptera: Tineina. London: Lovell Reeve; 1854. i-viii, $313 \mathrm{p}$.

29. Stonis JR, Diškus A, Remeikis A, Gerulaitis V, Karsholt O. Leaf-mining Nepticulidae (Lepidoptera) from record high altitudes: documenting an entire new fauna in the Andean páramo and puna. Monograph. Zootaxa. 2016; 4181(1): 1-94. doi:http://doi.org/10.11646/ zootaxa.4181.1.1

30. Stonis JR, Diškus A, Remeikis A, Karsholt O, Cumbicus Torres N. Illustrated review of the leaf-mining Nepticulidae of the central Andes (Peru and Bolivia). Monograph Zootaxa. 2017; 4257(1): 1-70. doi: https://doi. org/10.11646/zootaxa.4257.1.1

31. Stonis JR, Diškus A, Remeikis A, Navickaitè A. Study methods of Nepticulidae: micro-mounts of genitalia structures. In: Stonis JR, Hill SR, Diškus A, Auškalnis T, editors. Selected abstracts and papers of the First Baltic International Conference on Field Entomology and Faunistics. Vilnius: Edukologija Publishers; 2014. p. 32-35.

32. Vári L. South African Lepidoptera I. Descriptions of new leafmining Tineina. Annls. Transv. Mus. 1955; 22(3): 331-351.
Jonas Rimantas Stonis, Arūnas Diškus, Andrius Remeikis, Maria Alma Solis

AMERIKINĖMS BRACHINEPTICULA

GEN. NOV. IR MANONEURA DAVIS GENTIMS PRIKLAUSANČIOS RŪŠYS SU NEIPRASTAIS PATINO LYTINIAIS LATAKAIS (CATHREMA): NAUJA GENČIŲ KONCEPCIJA

\section{Santrauka}

Straipsnyje aprašoma nauja mokslui Brachinepticula gentis ir trys naujos rūšys: Brachinepticula plurilobata sp. nov., B. elongata sp. nov. ir Johanssoniella bina sp. nov. Pateikiamos diagnostinès schemos ir nauja taksonominė koncepcija, kuria remiantis pirmą kartą pripažįstamos keturios giminingos gentys: Johanssoniella Koçak, Brachinepticula gen. nov., Enteucha Meyrick ir Manoneura Davis. Genčių ir rūšių kataloge pateiktos naujos taksonominès pavadinimų kombinacijos ir nauji duomenys apie kai kurių rūšių morfologiją, biologiją bei paplitimą. Pirmą kartą dokumentuojama Amazonijoje surinkta Manoneura basidactyla (Davis), taip pat Johanssoniella diplocosma (Meyrick) medžiaga iš Himalajų. Pateikiami nauji tyrimų duomenys apie iki šiol nežinomas europinès Johanssonia acetosae (Stt.) patino genitalinių struktūrų morfologijos ypatybes. Straipsnis itin gausiai iliustruotas lapų pažeidimų (minų) ir morfologinių struktūrų nuotraukomis, piešiniais ir schemomis.

Raktažodžiai: Amerikos fauna, Brachinepticula Stonis \& Diškus, Enteucha Meyrick, Johanssoniella Koçak, lapų minos, Manoneura Davis, nauja gentis, naujos rūšys, Nepticulidae 